\title{
Origin and Evolution of the Ore-Forming Fluids in the Liyuan Gold Deposit, Central North China Craton: Constraints from Fluid Inclusions and H-O-C Isotopic Compositions
}

\author{
Ying Ma, ${ }^{1}$ Suo-Fei Xiong, ${ }^{1}$ Hua-Liang Li, ${ }^{1,2}$ and Shao-Yong Jiang ${ }^{1,3}$ \\ ${ }^{1}$ State Key Laboratory of Geological Processes and Mineral Resources, Faculty of Earth Resources, Collaborative Innovation \\ Center for Exploration of Strategic Mineral Resources, China University of Geosciences, Wuhan 430074, China \\ ${ }^{2}$ School of Earth Sciences, East China University of Technology, Nanchang 330013, China \\ ${ }^{3}$ State Key Laboratory for Mineral Deposits Research, School of Earth Sciences and Engineering, Nanjing University, \\ Nanjing 210093, China
}

Correspondence should be addressed to Shao-Yong Jiang; shyjiang@cug.edu.cn

Received 28 January 2017; Accepted 6 June 2017; Published 7 August 2017

Academic Editor: Paolo Fulignati

Copyright (C) 2017 Ying Ma et al. This is an open access article distributed under the Creative Commons Attribution License, which permits unrestricted use, distribution, and reproduction in any medium, provided the original work is properly cited.

\begin{abstract}
The Liyuan gold deposit is hosted within Archean basement metamorphic rocks and controlled by the NNE-trending faults in the central North China Craton. The ore-forming processes can be divided into three stages (early, middle, and late). Three types of primary fluid inclusions (FIs) are identified in the Liyuan, including pure carbonic, carbonic-aqueous, and aqueous inclusions. The primary FIs of three stages are mainly homogenized at temperatures of $318-408^{\circ} \mathrm{C}, 201-329^{\circ} \mathrm{C}$, and $136-229^{\circ} \mathrm{C}$, with salinities of $2.1-8.9,0.5-12.4$, and $0.4-6.3$ wt.\% $\mathrm{NaCl}$ equivalent, respectively. The main Au mineralization is related to the middle stage, and water-rock interaction caused rapid precipitation of gold in this stage. The initial ore-forming fluids were likely magmatic water or metamorphic fluid and mixed with meteoric water at later stages. Due to the lack of granite body at the present mining levels, we speculate that it was magmatic water that might have been exsolved from a concealed granite body at greater depth or it was metamorphic fluid that was directly transported from depth via deep faults. Based on all the available geological and geochemical evidence, we suggest that the Liyuan deposit belongs to orogenic gold deposit that located in the interior North China Craton.
\end{abstract}

\section{Introduction}

Orogenic gold deposits are a distinctive class of mineral deposit that has been the source for at least one-third of world gold production [1-3]. This type of deposits is widely recognized in both old cratonic blocks and younger Phanerozoic mobile belts and mainly formed during transpressional to compressional events in collisional or postcollisional tectonic settings $[1,2]$. The orogenic gold deposits usually show the following characteristics: (1) Orebodies are structurally controlled by the faults or brittle to ductile zones, and host rocks are deformed and variably metamorphosed. (2) Hydrothermal alteration assemblages mainly consist of quartz, sericite, sulfide, carbonate, and chlorite. (3) Oreforming fluids have low salinities (up to $12 \mathrm{wt} . \% \mathrm{NaCl}$ equivalent) and are mixtures of $\mathrm{H}_{2} \mathrm{O}$ and $\mathrm{CO}_{2}$, with less amounts of
$\mathrm{CH}_{4}$ and $\mathrm{N}_{2}$, and near-neutral $\mathrm{pH}$. (4) The mineralized lodes formed over a broad upper- to middle-crustal P-T conditions, between about $100-500 \mathrm{MPa}$ and $200-650^{\circ} \mathrm{C}[1,2,4-7]$.

Orogenic gold deposits are extremely important gold exploration targets in China which comprise nearly $50 \%$ of the gold resources [8-10]. Most of the gold deposits in China concentrate in the North China Craton (NCC), and many of them have geological and geochemical signatures which suggest an orogenic gold mineralization style (e.g., [2, 5, 8, 1114]). Previous studies on the gold deposits of NCC were mainly focused along the margin of the craton, such as the Jiaodong and Liaodong gold provinces (eastern margin), the Xiaoqinling gold province (southern margin), and the JibeiJidong and Chifeng-Chaoyang gold provinces (northern margin) (Figures 1(a) and 1(b)). However, few systematic investigations have examined the geology, geochemistry, 


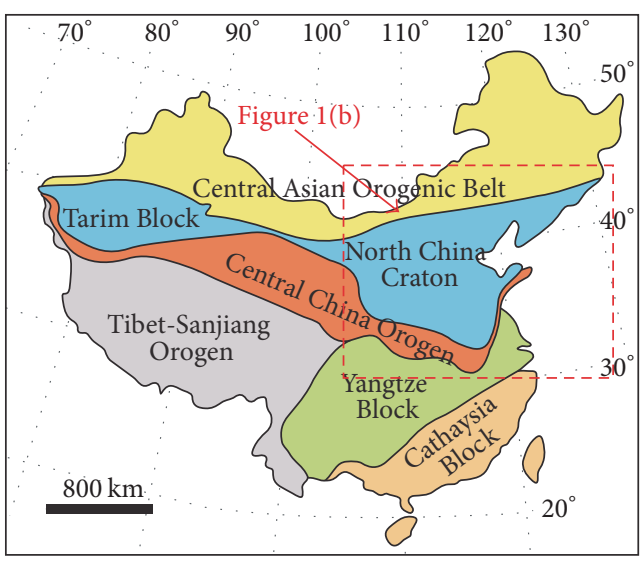

(a)

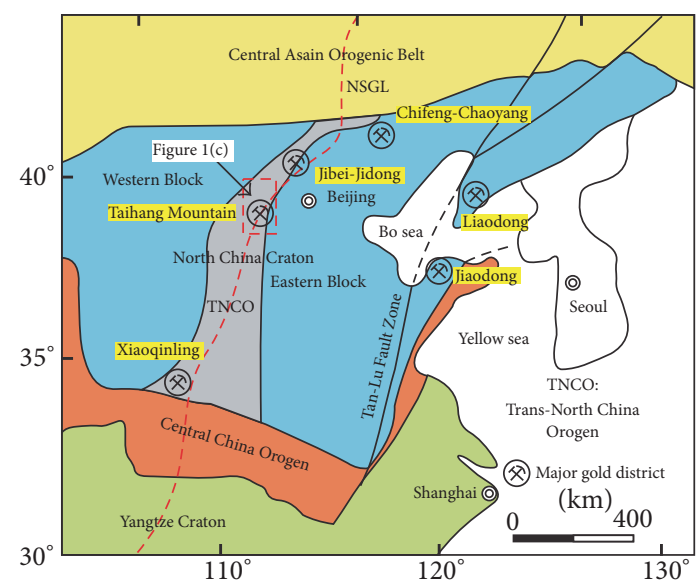

(b)

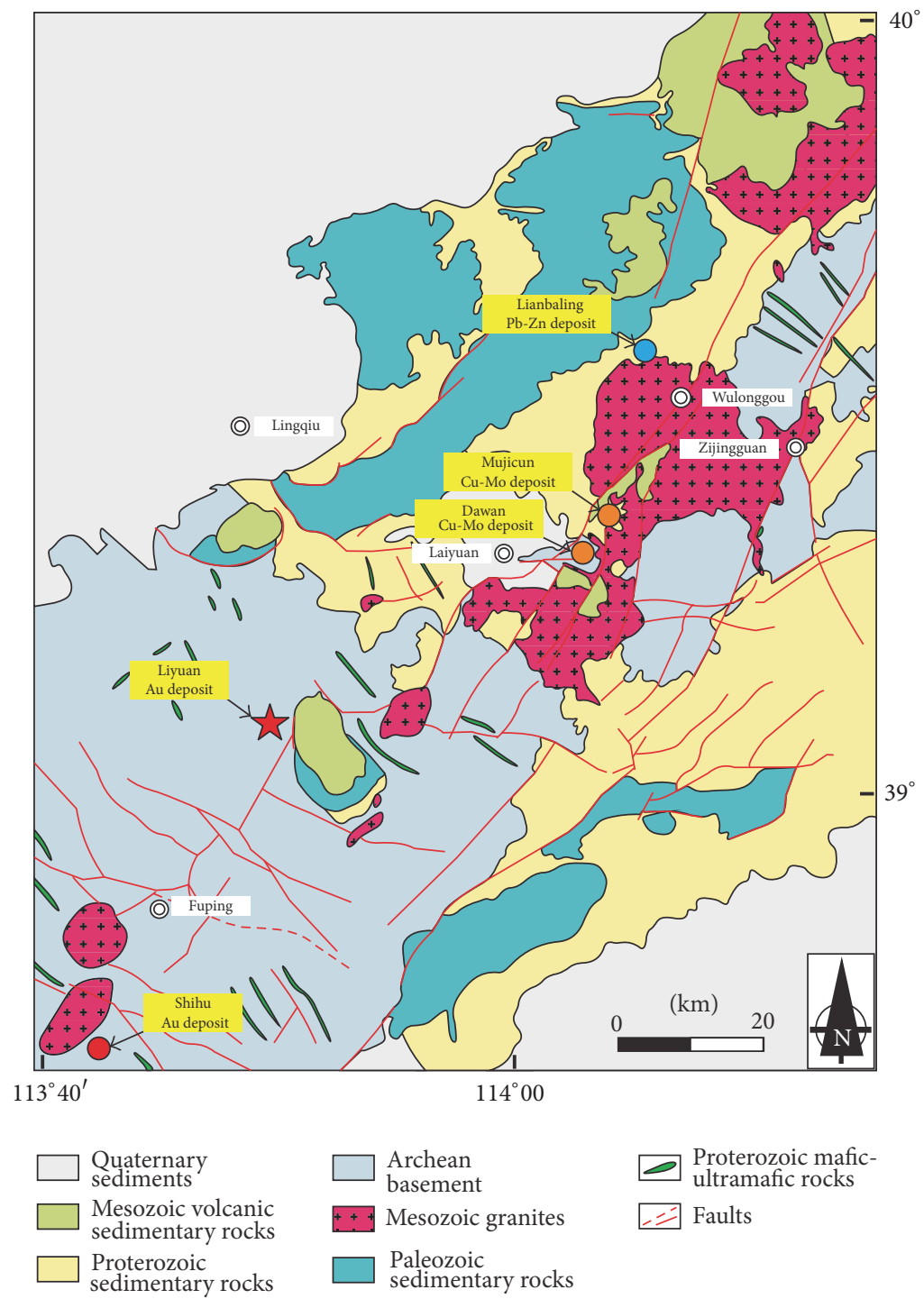

(c)

Figure 1: (a) Tectonic subdivisions of China, showing the location of the North China Craton (after [28]). (b) Tectonic settings of the North China Craton, also showing the major gold districts in the North China Craton (after [29]). (c) Regional geological map of the Liyuan gold deposit, modified after Wang et al. [21]. "Red-circle": Au deposit, "orange-circle": Cu-Mo deposit, and "sky blue-circle": Pb-Zn deposit. 
ore-controlling structures, and ore genetic style of gold deposits within the interior NCC such as those in the northern Taihang Mountains (TM) region, central NCC, which limits our understanding of gold mineralization process in the whole NCC.

Most of the gold deposits in the northern TM region are distributed within the Precambrian metamorphic rocks and are strictly controlled by the brittle-ductile fractures, which share many similar features (i.e., mineralization style, mineral compositions of ores, hydrothermal alterations, and characteristics of ore-forming fluids) with those of orogenic gold deposits worldwide [15-19]. Niu et al. [16, 17], Chen et al. [18], and Tian et al. [19] proposed that the deposits in the region belong to the metamorphic-hydrothermal or orogenic type gold deposits, whereas others (e.g., $[20,21]$ ) considered that the gold deposits were formed in magmatichydrothermal processes. The Shihu deposit is the largest gold deposit in the region with the gold resources of over $50 \mathrm{t}$ (an average grade of $5.9 \mathrm{~g} / \mathrm{t}$ ), and some studies have been carried out on the Shihu gold deposit (e.g., [20-24]). It is suggested that the Shihu gold deposit was formed at ca.141 Ma (Quartz ${ }^{40} \mathrm{Ar}^{-39} \mathrm{Ar}$ age), and the ore-forming fluids in this deposit were characterized by low salinity, mesothermal, and $\mathrm{CO}_{2}-\mathrm{H}_{2} \mathrm{O}-\mathrm{NaCl}$ system and were mainly derived from the lower crust with minor mantle component [20-22]. The Liyuan gold deposit is a newly discovered gold deposit in the northern TM region and is now still a small deposit due to the poor exploration work. $\mathrm{Xu}$ [25] has investigated the geology of this deposit and suggested that this deposit belongs to alteration rock type gold deposit controlled by fracture zone. Although temperature $\left(140-350^{\circ} \mathrm{C}\right)$, salinity $\left(1.8-12.6\right.$ wt.\% $\mathrm{NaCl}$ equivalent), density $\left(0.65-0.98 \mathrm{~g} / \mathrm{cm}^{3}\right)$, and $\mathrm{CO}_{2}$-bearing fluid inclusions in the main stage ores were reported by Ju et al. [26], these authors did not study the early stage ore-barren quartz and related generation of fluid inclusions. Furthermore, detailed stable isotopes studies of the ore-forming fluids with an aim to constraint the gold deposition mechanism and ore genesis of the Liyuan deposit are still lacking.

Gold deposits generally form as a consequence of tectonic, geological, and geochemical conditions [27], in which the nature and evolution of ore-forming fluids are of fundamental importance [6]. Thus, an accurate assessment of characteristics and nature of the ore-forming fluids is a key to understand the origin of the deposit. In this paper, we carried out detailed field work, a combined petrographic, microthermometric, and laser Raman analysis of fluid inclusions, and $\mathrm{H}-\mathrm{O}-\mathrm{C}$ isotope analyses, to constrain the origin and evolution of the ore-forming fluids of the Liyuan gold deposit, in an attempt to provide new evidence to enhance our understanding of the ore genesis, and to promote and guide further research onto the mineralization potential and further gold exploration in the northern TM region, central NCC.

\section{Regional Geology}

The North China Craton (NCC), located between the Central Asian Orogenic Belt (CAOB) to the north and the Central China Orogen (CCO) to the south, is one of the oldest and largest cratons in the East Asia (Figure 1(a), [35, 36]). The NCC consists of two Archean continental nuclei, the Western Block (WB), and the Eastern Block (EB), separated by the Trans-North China Orogen (TNCO) that formed at ca. $1.85 \mathrm{Ga}$ during collision between the two blocks (Figure 1(b), [37-39]).

The Liyuan gold deposit is located in the northern Taihang Mountains (TM) in the TNCO. The basement of the region is composed of Archean Fuping Group amphibolite- to granulite-facies metamorphic rocks consisting of tonalite-trondhjemite-granodiorite (TTG) gneisses, migmatite, amphibolite, and minor amounts of supracrustal rocks, with metamorphic ages at ca. 1.92-1.80 Ga [40-43]. The basement rocks are unconformably covered by Proterozoic and Paleozoic clastic and calcareous strata, including a thick succession of ca. $1400 \mathrm{Ma}$ dolomite (Gaoyuzhuang Formation), 1310-1207 Ma cherty dolomite (Wumishan Formation), and Cambrian-Ordovician limestone (Mantou Formation and Zhangxia Formation) and a Mesozoic sequence of volcanic-sedimentary rocks (Tiaojishan Formation). Serval Mesozoic granitoids occur in the northern TM region. Moreover, various mafic-ultramafic dikes, including diabase, gabbro, and lamprophyre, are widespread in the area. Most of these dikes are NW-striking (although some are NE-striking) and were emplaced into Archean metamorphic rocks and Proterozoic sedimentary rocks (Figure 1(c), [21, 44-47]).

The main geologic structures of the northern TM region are nearly NW-trending folds and NNE-trending faults. The folds which were formed primarily during Mesoarchean to Paleoproterozoic are coeval with the NNE-trending faults carrying the late Paleoproterozoic mafic-ultramafic dikes [48, 49], while the regional NNE-trending faults, which cut across the Precambrian basement and Paleozoic strata, are mainly associated with the Mesozoic (Yanshanian) tectonic events [50, 51]. Numerous $\mathrm{Au}, \mathrm{Ag}, \mathrm{Cu}, \mathrm{Mo}, \mathrm{Pb}$, and $\mathrm{Zn}$ ore deposits, including the Liyuan gold deposit discussed in this paper, and the Lianbaling $\mathrm{Pb}-\mathrm{Zn}$, Mujicun $\mathrm{Cu}-\mathrm{Mo}$, Dawan $\mathrm{Cu}-\mathrm{Mo}$, and Shihu Au deposits, are distributed along the regional NNEtrending faults $[52,53]$ (Figure $1(\mathrm{c})$ ).

The Mesozoic magmatism in the northern TM region consists of volcanic rocks (Tiaojishan Formation) and large amounts of granitoids. The Tiaojiashan Formation with the age between 170 and $139 \mathrm{Ma}$ is mainly composed of andesitic lava, tuff, and brecciated diorite porphyry [54-56]. Numerous Mesozoic granitoids such as Wanganzhen, Mapeng, and Chiwawu batholiths (with recent obtained LA-ICP-MS and SHRIMP zircon U-Pb ages of 140-125 Ma) [57-59] are distributed along the NNE-trending faults in the region.

\section{Geology of the Liyuan Gold Deposit}

The Liyuan gold deposit $\left(39^{\circ} 05^{\prime} 00^{\prime \prime}\right.$ to $39^{\circ} 05^{\prime} 45^{\prime \prime} \mathrm{N}$, $114^{\circ} 18^{\prime} 30^{\prime \prime}$ to $114^{\circ} 19^{\prime} 30^{\prime \prime} \mathrm{E}$ ) is located in the central part of the northern TM region, $72 \mathrm{~km}$ south of the county of Lingqiu in northern Shanxi Province, China (Figure 1(c)). The gold orebodies are mainly hosted in the metamorphic rocks of the Archean Fuping Group gneisses and Archean coarsegrained K-feldspar granite (Figure 2, [26]). There are tens of NW-tending diabase dikes in the mining area, and some 


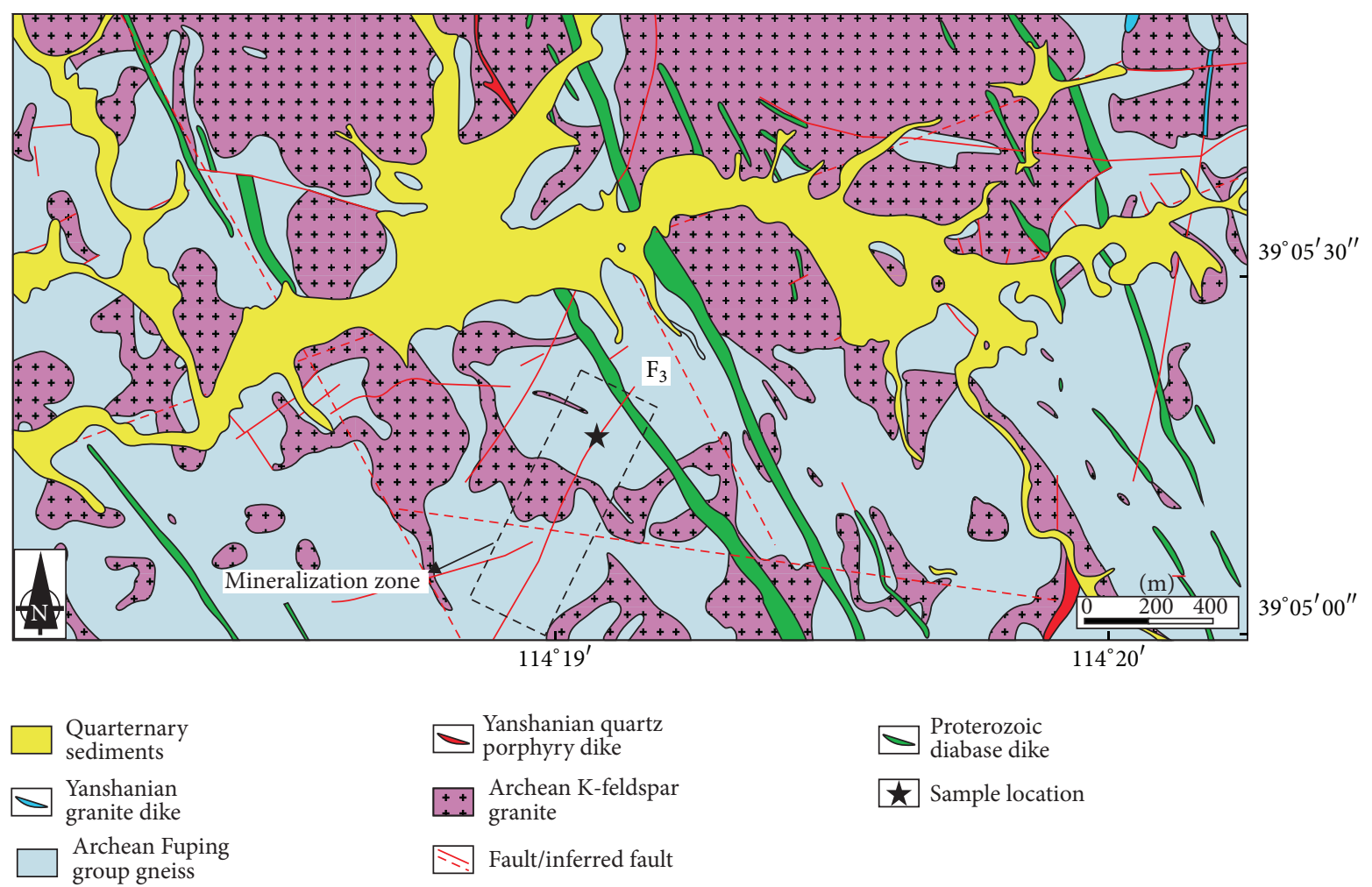

Figure 2: Geological map of the Liyuan gold deposit (modified after Ju et al. [26]).

diabase dikes are cross cut by the auriferous quartz veins and have been strongly deformed and altered (Figure 3(a)). LAICP-MS zircon U-Pb analyses demonstrate that the emplace age of these diabase rocks is $1788 \pm 13 \mathrm{Ma}$ (our unpublished data). No granitic body has been found at the current mining levels at Liyuan, except for a few intermediate-felsic dikes, which trend NNE and NNW and are mainly composed of quartz porphyry and fine-grained granite that intruded to the Precambrian basement and yielded a LA-ICP-MS zircon $\mathrm{U}-\mathrm{Pb}$ age of $134 \pm 1 \mathrm{Ma}$ (Figure 2, our unpublished data).

Structurally, the ore district is characterized by the NWtrending anticline and some younger NNE-, NW-, and nearly $\mathrm{W}$-E-trending faults. The $\mathrm{F}_{3}$ fault is approximately 2,000 meters long and tens of centimeters to 15 meters wide, trending from $10^{\circ}-30^{\circ}$ and dipping $45^{\circ}-65^{\circ}$ to NW. Hydrothermal breccias, cataclastic rocks, and fault gouge are well developed along the faults, which may indicate multiple deformation events under different structural regimes [60]. Orebodies are mostly restricted to alteration zones developed along the NNE-trending $\mathrm{F}_{3}$ fault and its subsidiary faults (Figure 2). In addition, the NW-trending faults were formed primarily during the Precambrian and filled with diabase dikes, and many orebodies are cut by nearly W-E-trending postmineralization faults (Figure 2).

Currently, three orebodies are mined in the Liyuan gold deposit. The mineralization features can be best represented by the largest number I orebody, which is controlled by the NNE-trending $\mathrm{F}_{3}$ fault [25]. This orebody is more than $400 \mathrm{~m}$ long and $2-5 \mathrm{~m}$ wide (average $3.5 \mathrm{~m}$ ), with strike $10^{\circ}-30^{\circ}$ and dips to northwest at an angle of $45^{\circ}-65^{\circ}$. The gold grade of the number I orebody is up to $300.0 \mathrm{~g} / \mathrm{t}$ Au with an average of $3.7 \mathrm{~g} / \mathrm{t}$, and the associated $\mathrm{Ag}$ is also of economic interests.

In the Liyuan gold deposit, the mineralization styles include veins, stockworks, disseminations, banded, and brecciated ores (Figure 3). The Au-Ag series minerals (i.e., Agbearing native gold and Au-bearing native silver) are mainly found within the quartz-polymetallic sulfide veins/veinlets. Ag-bearing native gold typically occurs along the boundaries between pyrite and quartz (or other sulfides) (Figures 4(f) and $4(\mathrm{~g})$ ) or within the microfractures of pyrite (Figure $4(\mathrm{~h})$ ). Au-bearing native silver commonly occurs as inclusions within pyrite or quartz (Figure 4(i)). In addition, these veins/veinlets also comprise pyrite, galena, sphalerite, minor chalcopyrite, magnetite, and argentite. Most of the gold ores are associated with pyrite. Pyrite is the predominant sulfide mineral (over $80 \%$ of the total metallic minerals), shows euhedral to subhedral and granular crystals, and exhibits metasomatic dissolution textures (Figure 4). The gangue minerals include over $85 \%$ quartz with minor amounts of sericite, muscovite, K-feldspar, chlorite, ankerite, calcite, and clay minerals (Figure 4).

Hydrothermal alteration is well developed in the Liyuan deposit, and the main alteration types include silicic, Kfeldspar, sericite, chlorite, and carbonate alterations. Silicic alteration usually occurs as fine-grained quartz coexisting with sericite and muscovite in the alteration zone (Figures 4(a) and 4(b)) or presents as quartz-sulfide veinlets or stockworks (Figures $3(\mathrm{c})-3(\mathrm{~g})$ ). Pyrite shows a close association 


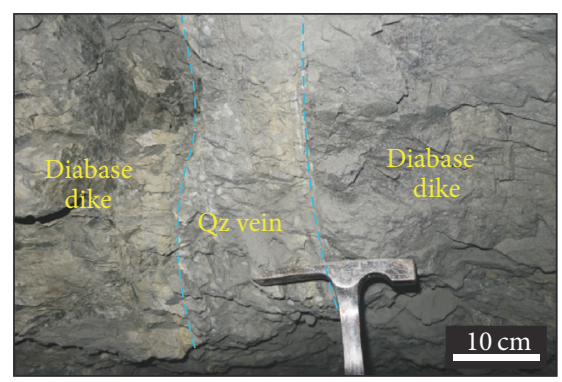

(a)

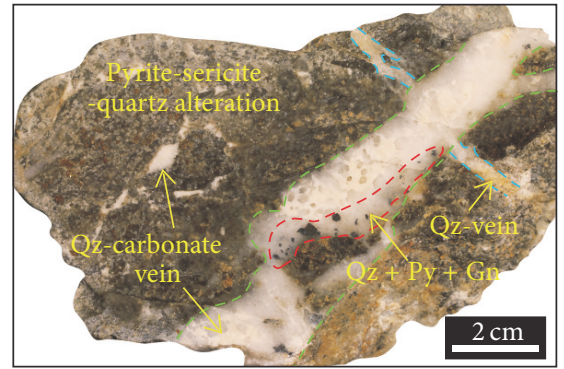

(d)

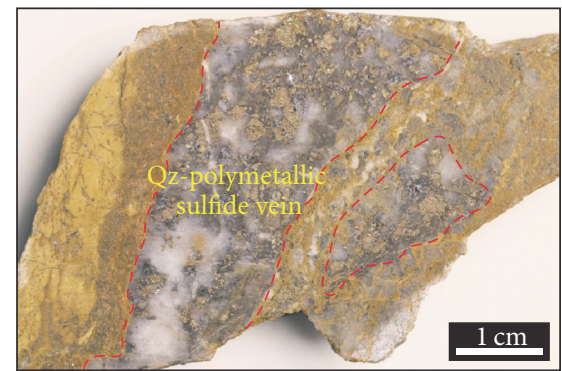

(g)

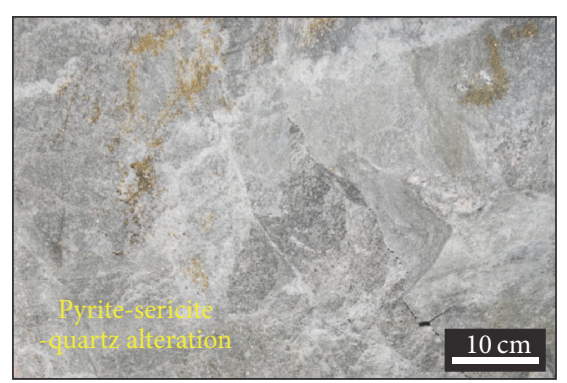

(b)

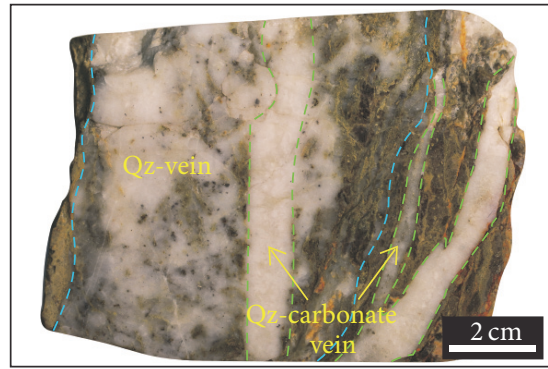

(e)

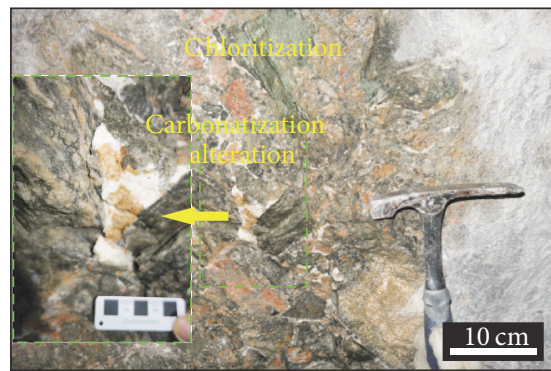

(h)

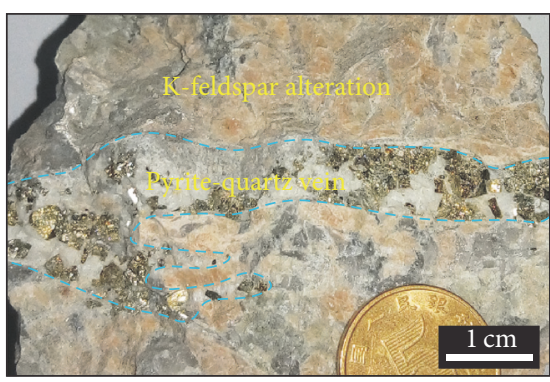

(c)

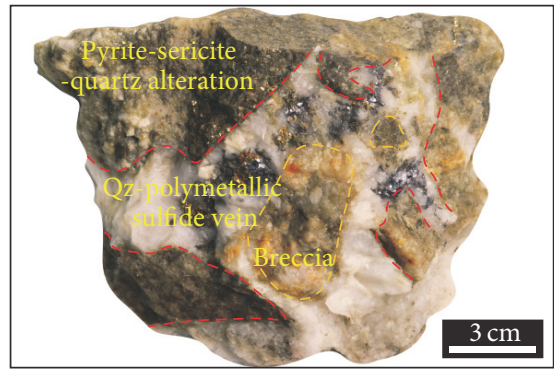

(f)

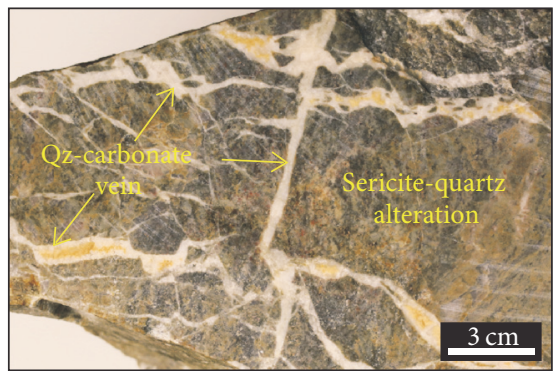

(i)

FIGURE 3: Photographs showing the mineral assemblages and cross-cutting relationships of different mineralization stage at the Liyuan gold deposit. (a) Early stage quartz vein cut a diabase dike. (b) Pyrite-sericite-quartz alteration in the early stage. (c) Early stage pyrite-quartz vein in association with K-feldspar alteration. (d) Early stage quartz vein cross cut by late stage quartz-carbonate vein, while the middle stage quartz-polymetallic vein was infilled by late stage quart-carbonate vein. (e) Early stage ore-barren quartz vein cemented by late stage quartz-carbonate vein. (f) Middle stage quartz-polymetallic vein occurring in pyrite-sericite-quartz alteration rock. (g) The Middle stage quartz-polymetallic vein. (h) The broken and brecciated pyrite-sericite-quartz rock and chlorite-altered rock fulfilled by late stage carbonate. (i) Late stage quartz-carbonate veinlets filling the extension joints in sericite-quartz alteration rock.

with silicic and sericite alteration and forms pyrite-sericitequartz alteration rocks (Figures $3(\mathrm{~b})$ and $3(\mathrm{~d})$ ), and of course the pyrite also occurs in the auriferous quartz veins (Figures 3(c), 3(d), 3(f), and 3(g)). Carbonate alteration is widespread during the postore hydrothermal stage, which mainly consists of calcite and ankerite (Figures 3(h), 3(i), and $4(\mathrm{c})$ ). Three hydrothermal stages have been identified in the Liyuan gold deposit on the basis of field evidence, mineralogical assemblages, petrographic observation, and cross-cutting relationships. The hydrothermal ore-forming process can be subdivided into an early quartz stage, a middle quartz-polymetallic sulfide stage, and a late quartz-carbonate stage (Figure 5).

The early stage is characterized by pyrite-sericitequartz alteration rocks (Figure 3(b)) or in places ore-barren quartz veins (Figures 3(a) and 3(c)). Minerals comprise coarse-grained milky white subhedral to anhedral quartz, sericite, muscovite (Figure 4(a)), and sparsely distributed minor coarse- to medium-grained, euhedral to subhedral pyrite. A small amount of Au-Ag series minerals is observed in this stage. Besides, the early stage quartz veins are commonly fractured and locally cut or cemented by middle stage and late stage veins (Figures 4(d) and 4(e)).

The middle stage, characterized by the quartzpolymetallic sulfide veins (Figures $4(\mathrm{f})$ and $4(\mathrm{~g})$ ), represents the most important gold-producing stage. Quartz in this stage is fine-grained and smoky gray and commonly shows no significant deformation, which indicates its formation in an extensional setting without compressional deformation. Sulfides, including pyrite, chalcopyrite, sphalerite, and galena, show coarse- to medium-grained euhedral crystals or subhedral aggregates and make up approximately 


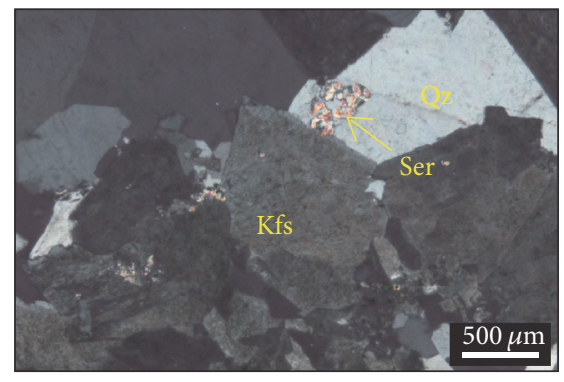

(a)

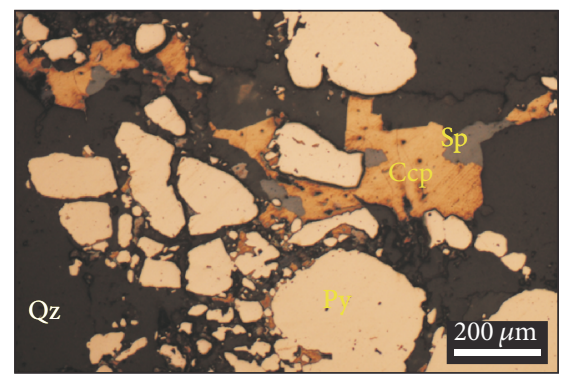

(d)

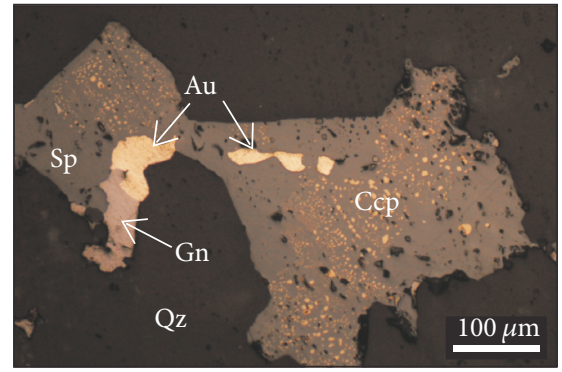

(g)

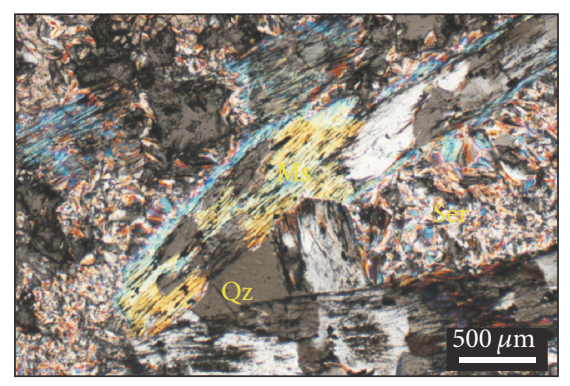

(b)

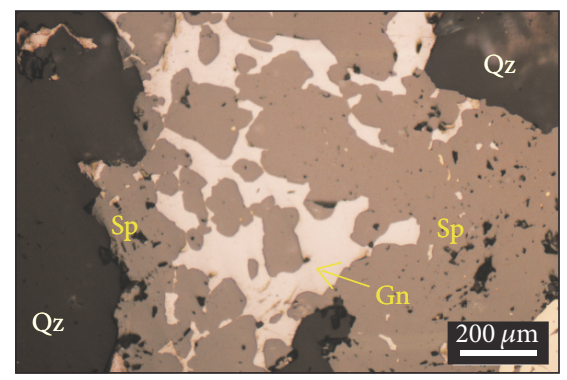

(e)

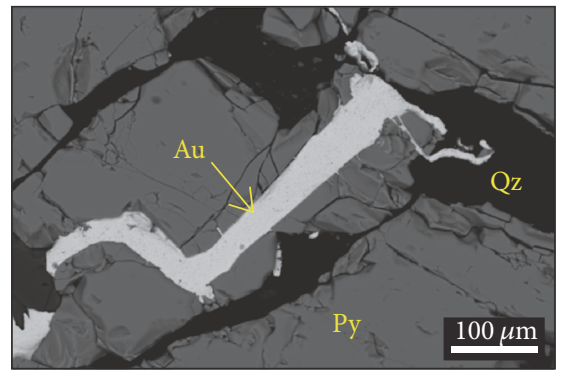

(h)

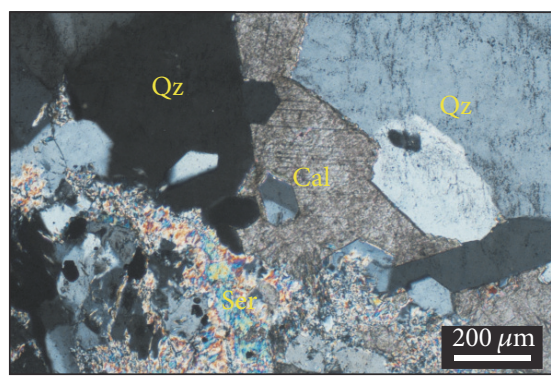

(c)

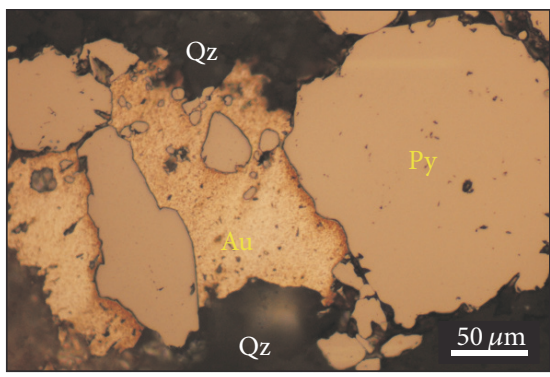

(f)

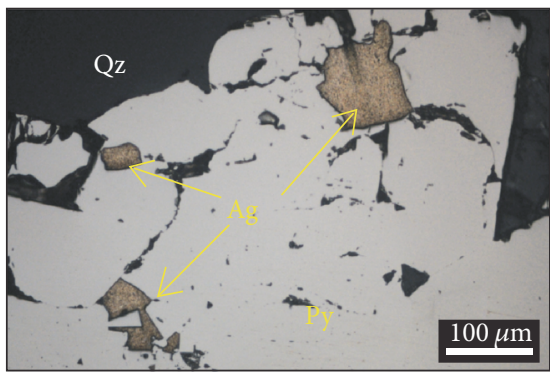

(i)

FIGURE 4: Photomicrographs under transmitted light $(\mathrm{a}-\mathrm{c})$, reflected light $(\mathrm{d}-\mathrm{g}, \mathrm{i})$, and back-scattered electronic images (h) showing the minerals and alteration assemblages in the Liyuan gold deposit. (a) K-feldspar occurring as an early alteration product intergrowth with quartz and sericite. (b) Typical sericite alteration consisting of sericite and muscovite. (c) Quartz-calcite vein with quartz-sericite alteration. (d) Middle stage chalcopyrite and sphalerite replacing the early stage deformed pyrite. (e) Middle stage sphalerite replaced by galena. (f) Agbearing native gold replacing the pyrite. (g) Ag-bearing native gold occurring as interstitial fillings between sphalerite, galena, and quartz or as irregular in sphalerite. (h) Ag-bearing native gold filling the microfracture of the pyrite. (i) Irregular Au-bearing native silver grains in pyrite. Ser: “sericite”; Ms: “muscovite”; Qz: “quartz”; Cal: “calcite”; Py: pyrite; Ccp: “chalcopyrite”; Sp: "sphalerite”; Gn: "galena”; Au: “Ag-bearing native gold"; Ag: "Au-bearing native silver."

10 vol.\% of the minerals (Figures $4(\mathrm{~d})$ and $4(\mathrm{e})$ ). Ores mainly occur as Ag-bearing native gold and Au-bearing native silver that coexist with other sulfides (Figures $4(\mathrm{f})-4(\mathrm{i}))$.

The late stage is characterized by carbonate cementing early stage hydrothermal altered breccias (Figure $4(\mathrm{~h})$ ) or quartz-carbonate veins and veinlets cross-cutting the alteration rocks and veins formed during the earlier two stages (Figures 3(d), 3(e), 3(i), and 4(b)). There occurs trace amount of pyrite, without other sulfides precipitating during this stage. The late stage quartz-carbonate veins filling the extension joints in the sericite-quartz alteration rocks, demonstrating the minerals, were crystallized in an extensional setting (Figure 4(i)).

\section{Analytical Methods}

4.1. Fluid Inclusion Measurements. Twenty-six doubly polished thin sections (about $200 \mu \mathrm{m}$ thick) for fluid inclusion study were selected from three mineralization stages in number I orebody of the Liyuan gold deposit. Fluid inclusions were carefully observed to identify their genetic and compositional types, vapour-liquid ratios, and spatial distribution. Eleven samples (three samples for early stage, five samples for middle stage, and three samples for late stage) with abundant and representative fluid inclusions were selected for microthermometric measurements and laser Raman spectroscopic analyses.

Fluid inclusion petrographic study was conducted using a Nikon Eclipse LV100POL microscope at the National 


\begin{tabular}{|l|l|l|l|}
\hline \multicolumn{1}{|c|}{ Mineral } & Early stage & Middle stage & Late stage \\
\hline Quartz & & & \\
K-feldspar & Sericite & & \\
Muscovite & & & \\
Pyrite & & & \\
Ag-bearing gold & & & \\
Au-bearing silver & & & \\
Chalcopyrite & & & \\
Sphalerite & & & \\
Galena & & - & \\
Ankerite & & & \\
Chlorite & & & \\
Calcite & & & \\
\hline
\end{tabular}

Figure 5: Paragenetic assemblages of gangue and ore minerals in the Liyuan gold deposit. Line thickness represents relative amount of the minerals.

Demonstration Center for Experimental Mineral Exploration Education, China University of Geosciences (Wuhan). Microthermometric measurements were carried out using a Linkam THMS-600 heating-freezing stage (from -196 to $600^{\circ} \mathrm{C}$ ) which is attached to a Leica DM2700P microscope connected to a television camera and screen at the China University of Geosciences (Wuhan). The stages were calibrated with synthetic fluid inclusions of pure $\mathrm{H}_{2} \mathrm{O}$ (ice melting temperature $=0{ }^{\circ} \mathrm{C}$; critical temperature $=374.1^{\circ} \mathrm{C}$ ) and pure $\mathrm{CO}_{2}\left(\mathrm{CO}_{2}\right.$ melting temperature $\left.=-56.6^{\circ} \mathrm{C}\right)$. The heating/freezing rate is generally $0.2-5.0^{\circ} \mathrm{C} / \mathrm{min}$ but was reduced to $<0.2^{\circ} \mathrm{C} / \mathrm{min}$ near the phase transformation. The uncertainties for the measurements are $\pm 0.5, \pm 0.2$ and $\pm 2.0^{\circ} \mathrm{C}$ for runs in the range of -120 to $-70^{\circ} \mathrm{C},-70$ to $100^{\circ} \mathrm{C}$, and 100 to $600^{\circ} \mathrm{C}$, respectively. Ice melting temperatures were observed at a heating rate of less than $0.1^{\circ} \mathrm{C} / \mathrm{min}$ and homogenization temperatures at rate of $\leq 1^{\circ} \mathrm{C} / \mathrm{min}$.

Five parameters of phase transformation were recorded, including final ice melting temperature $\left(T_{\text {m-ice }}\right)$, melting temperature of clathrate $\left(T_{\mathrm{m} \text {-cla }}\right)$, melting temperature of solid $\mathrm{CO}_{2}\left(T_{\mathrm{m}-\mathrm{CO}_{2}}\right)$, homogenization temperature of $\mathrm{CO}_{2}$ liquid and vapour $\left(T_{\mathrm{h}-\mathrm{CO}_{2}}\right)$, and total homogenization temperature $\left(T_{\mathrm{h}}\right)$, depending on the types of FIs. Salinities were calculated using the equations of Bodnar [61] for aqueous fluid inclusions and of Collins [62] for aqueous-carbonic fluid inclusions. Densities and pressures were estimated using the Flincor software [32] packages according to microthermometric data for $\mathrm{CO}_{2}-\mathrm{H}_{2} \mathrm{O}-\mathrm{NaCl}$ system [33]

Fluid inclusion laser Raman spectroscopy analyses were performed at the State Key Laboratory of Geological Process and Mineral Resources, China University of Geosciences (Wuhan), using a Renishaw RM-1000 Raman microscope. The laser source was an argon laser with a surface power of $5 \mathrm{~mW}$ for exciting the radiation $(514.5 \mathrm{~nm})$. The area of charge-coupled device (CCD) detector is $20 \mu \mathrm{m}^{2}$, and the scanning range of spectra was set between 1200 and $3800 \mathrm{~cm}^{-1}$, with an accumulation of $30 \mathrm{~s}$ for each scan and spectral resolution of $\pm 2 \mathrm{~cm}^{-1}$. Instruments settings were kept constant during all analyses.

4.2. Hydrogen, Oxygen, and Carbon Isotope Analyses. Four quartz samples were selected for mineral oxygen and fluid inclusion hydrogen and carbon isotope analyses, and they represent the corresponding early (LY13-1-6), middle (LY132-1 and LY13-2-11), and late stages (15LYD-12). All the samples were crushed into 40-60 meshes and pure quartz separates were selected. The hydrogen, oxygen, and carbon isotopes were analyzed on a Finnigan MAT253 mass spectrometer in the Laboratory of Stable Isotope Geology, Chinese Academy of Geological Sciences, Beijing. Oxygen $\left(\mathrm{O}_{2}\right)$ was generated from the quartz by quantitatively reaction with $\mathrm{BrF}_{5}$ [34] and converted to $\mathrm{CO}_{2}$ on a platinum-coated carbon rod. Water extracted from the fluid inclusions within quartz separates was reacted with zinc at ca. $400^{\circ} \mathrm{C}$ and the released $\mathrm{H}_{2}$ for mass spectrometric measurement. $\mathrm{CO}_{2}$ was liberated from carbonic fluid inclusions in quartz separates by thermal decrepitation under vacuum and then measured for $\delta^{13} \mathrm{C}$ by mass spectrometry. The results were normalized to $\mathrm{V}$ SMOW standards and the precisions were $\pm 2 \%$ for $\delta \mathrm{D}$ and $\pm 0.2 \%$ for $\delta^{18} \mathrm{O}$ and $\delta^{13} \mathrm{C}$. The oxygen isotope values of water in equilibrium with the minerals were calculated using the fractionation formula $1000 \ln \alpha_{\text {quartz- } \mathrm{H}_{2} \mathrm{O}}=3.38 \times 10^{6} T^{-2}-$ 3.40 reported by Clayton et al. [34], where $T$ is the mean value of the homogenization temperature of fluid inclusions from the same quartz samples plus pressure-corrected temperature as discussed below.

\section{Results}

5.1. Petrography and Types of Fluid Inclusions. Fluid inclusions (FIs) occurring as isolated inclusions, randomly distributed groups, or in clusters were considered to be primary or pseudosecondary in origin, whereas those aligned along microfractures in transgranular trails were interpreted as secondary $[63,64]$. Three types, including aqueous-carbonic fluid inclusions (C-type), pure carbonic fluid inclusions (PCtype), and aqueous fluid inclusions (W-type), were identified in quartz and calcite grains from the Liyuan gold deposit based on their phases at room temperature $\left(25^{\circ} \mathrm{C}\right)$, phase transitions observed during heating and freezing, and compositions by using laser Raman spectroscopy. The classification of the FIs in this study is also consistent with previous study carried out by Ju et al. [26].

5.1.1. Aqueous-Carbonic Fluid Inclusions (C-Type). The Ctype FIs are the most abundant type in the quartz grains of early and middle stages, which occupy $50 \%$ of the total primary FIs. They consist of two (liquid $\mathrm{H}_{2} \mathrm{O}+$ liquid $\mathrm{CO}_{2}$ ) or three phases (liquid $\mathrm{H}_{2} \mathrm{O}+$ liquid $\mathrm{CO}_{2}+$ vapour $\mathrm{CO}_{2}$ ) at room temperature $\left(25^{\circ} \mathrm{C}\right.$ ) (Figures $6(\mathrm{a})-6(\mathrm{~d})$ ), with the $\mathrm{CO}_{2}$ volumetric proportion ranges of $10 \%$ to $90 \%$. C-type FIs show ellipsoidal, irregular, or negative crystal shapes with sizes ranging from 4 to $30 \mu \mathrm{m}$ (mostly 5-15 $\mu \mathrm{m}$ ). 


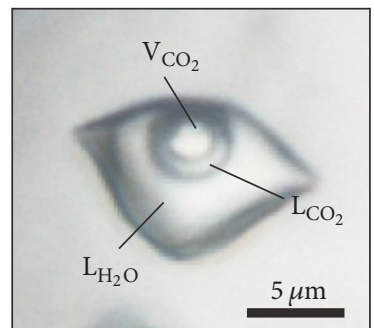

(a)

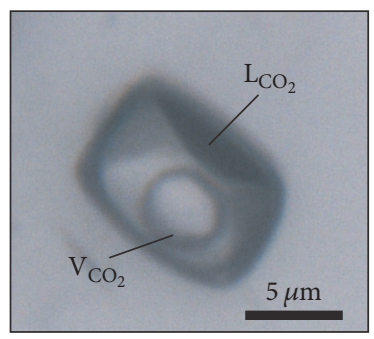

(e)

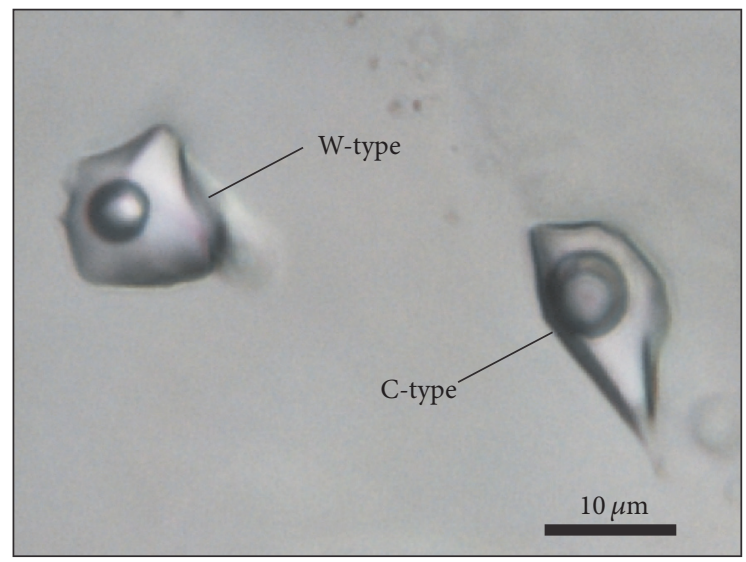

(i)

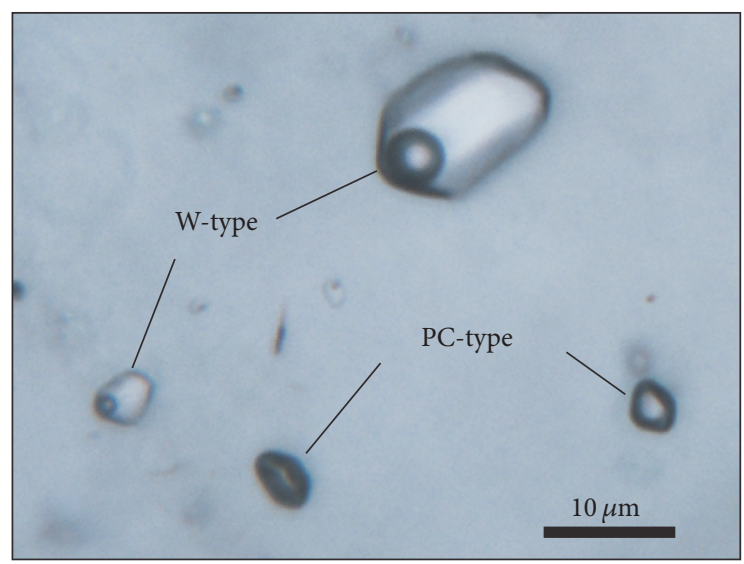

(k)

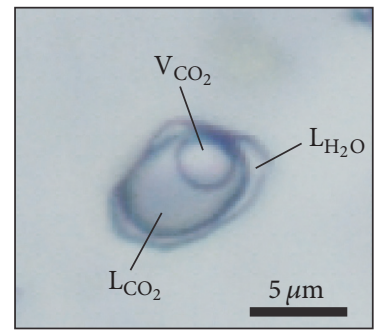

(b)

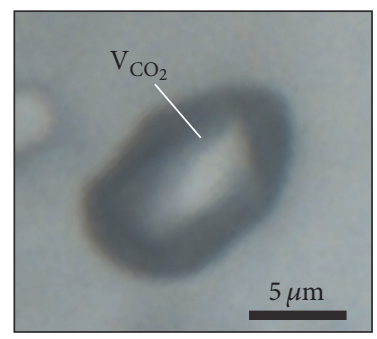

(f)

(g)

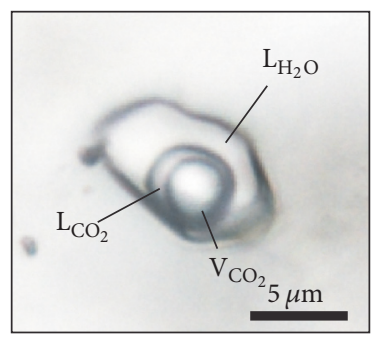

(d)
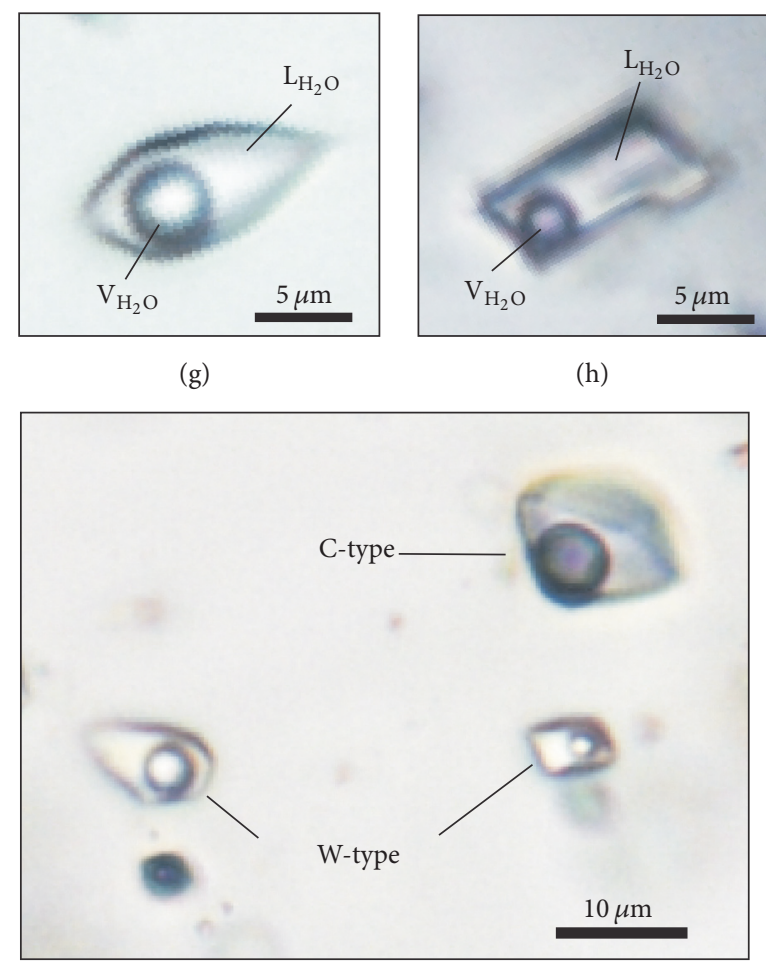

(j)

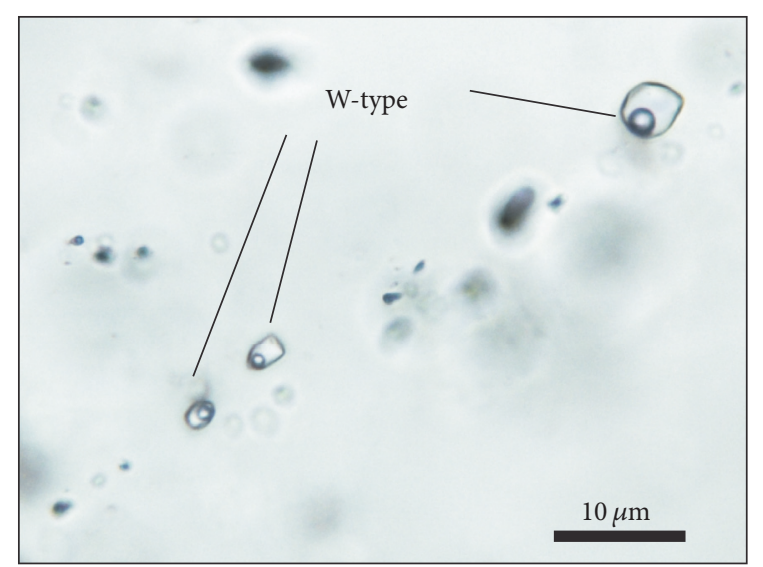

(1)

Figure 6: Photomicrographs showing typical fluid inclusions observed in the Liyuan gold deposit. (a) Liquid-rich C-type fluid inclusion in early stage quartz. (b) Vapour-rich C-type fluid inclusion in early stage quartz. (c, d) Liquid-rich C-type fluid inclusions in middle stage quartz. PC-type FIs in early stage (e) and middle stage (f) quartz. (g) W-type fluid inclusion in late stage quartz. (h) W-type fluid inclusion in late stage calcite. (i) Coexisting W-type and PC-type fluid inclusions in middle stage quartz. (j, k) Coexistence of the C-type and W-type fluid inclusions in middle stage quartz. (l) Secondary W-type fluid inclusions in a linear distribution in late stage quartz. $\mathrm{V}_{\mathrm{CO}_{2}}$ : vapour $\mathrm{CO}_{2}$; $\mathrm{L}_{\mathrm{CO}_{2}}$ : liquid $\mathrm{CO}_{2} ; \mathrm{V}_{\mathrm{H}_{2} \mathrm{O}}$ : vapour $\mathrm{H}_{2} \mathrm{O} ; \mathrm{L}_{\mathrm{H}_{2} \mathrm{O}}$ : liquid $\mathrm{H}_{2} \mathrm{O}$. 
5.1.2. Pure Carbonic Fluid Inclusions (PC-Type). The PC-type FIs, accounting for approximately $10 \%$ of the total primary FIs population, are mono- (vapour or liquid $\mathrm{CO}_{2}$ ) or two-phase (liquid $\mathrm{CO}_{2}+$ vapour $\left.\mathrm{CO}_{2}\right)$ at room temperature $\left(25^{\circ} \mathrm{C}\right.$ ) (Figures 6(e) and 6(f)) and commonly coexist with C-type FIs in the early and middle stages. They usually show oval and irregular shapes with the size varying between 4 and $12 \mu \mathrm{m}$.

5.1.3. Aqueous Fluid Inclusions (W-Type). The W-type FIs are present in all mineralization stages and account for $40 \%$ of the total FIs population. They commonly appear as two-phase (liquid $\mathrm{H}_{2} \mathrm{O}+$ vapour $\left.\mathrm{H}_{2} \mathrm{O}\right)$ FIs at room temperature $\left(25^{\circ} \mathrm{C}\right)$, with bubbles accounting for 5-20\% in volume (Figures 6(g) and $6(\mathrm{~h}))$. The W-type FIs are negative crystal, ellipsoidal, and irregular in shape and 2 to $15 \mu \mathrm{m}$ in size. They commonly occur in an assemblage with C- and PC-type FIs in the middle mineralization stage (Figures $6(\mathrm{i})-6(\mathrm{k})$ ). In addition, the primary W-type FIs occur as isolated or clusters, whereas some W-type FIs may distribute along microfractures (Figure 6(l)), indicating a secondary origin.

5.2. Microthermometry. Microthermometric data collected for the C-, W-, and PC-type primary fluid inclusions of the three mineralization stages are summarized in Table 1 and presented in Figures 7 and 8, which clearly show the association between mineral assemblages, physic-chemical conditions, and mineralization stages. The microthermometric data from Ju et al. [26] of middle and late stages are also listed in Table 1 for comparison.

5.2.1. Early Stage. Fluid inclusions in the early stage quartz are dominantly $\mathrm{C}$-type and $\mathrm{W}$-type, with minor PC-type FIs. The melting temperatures $\left(T_{\mathrm{m}-\mathrm{CO}_{2}}\right)$ of solid $\mathrm{CO}_{2}$ in the $\mathrm{C}$ type FIs range from -58.3 to $-56.8^{\circ} \mathrm{C}$ (Figure $7(\mathrm{a})$ ), which is very close to triple point of pure $\mathrm{CO}_{2}\left(-56.6^{\circ} \mathrm{C}\right)$ and indicates that the carbonic phase in these FIs is nearly pure $\mathrm{CO}_{2}$. Clathrate melting temperatures $\left(T_{\mathrm{m} \text {-cla }}\right)$ show a range from 5.6 to $8.9^{\circ} \mathrm{C}$, with corresponding salinities from 2.2 to 8.2 wt.\% $\mathrm{NaCl}$ equivalent (Figure 8(b)). The carbonic phase $\left(\mathrm{T}_{\mathrm{h}-\mathrm{CO}_{2}}\right)$ of C-type FIs was homogenized to liquid from 18.6 to $29.5^{\circ} \mathrm{C}$ (Figure $7(\mathrm{a})$ ). The total homogenization temperatures $\left(T_{\mathrm{h}}\right)$ of C-type FIs range from 318 to $392^{\circ} \mathrm{C}$ (Figure $8(\mathrm{a})$ ), generally homogenized to both liquid and vapour phases and with no systematic difference among homogenizing to liquid or vapour. The calculated $\mathrm{CO}_{2}$ densities range from 0.62 to $0.79 \mathrm{~g} / \mathrm{cm}^{3}$ and bulk densities from 0.71 to $0.96 \mathrm{~g} / \mathrm{cm}^{3}$ (Table 1). For PC-type FIs, melting temperatures $\left(T_{\mathrm{m}-\mathrm{CO}_{2}}\right)$ of solid $\mathrm{CO}_{2}$ show a range from -58.1 to $-56.9^{\circ} \mathrm{C}$ (Figure 7(a)), suggesting that the components of these inclusions are nearly pure $\mathrm{CO}_{2}$. The homogenization temperatures $\left(T_{\mathrm{h}-\mathrm{CO}_{2}}\right.$ ) of $\mathrm{CO}_{2}$ are 19.8 to $30.2^{\circ} \mathrm{C}$ (all homogenize to liquid phase) (Figure $7(\mathrm{~b})$ ), with corresponding densities of 0.59 to $0.78 \mathrm{~g} / \mathrm{cm}^{3}$. The $\mathrm{W}$-type inclusions yield final ice melting temperatures $\left(T_{\text {m-ice }}\right)$ of -5.8 to $-1.2^{\circ} \mathrm{C}$ and salinities of $2.1-8.9$ wt. $\% \mathrm{NaCl}$ equivalent (Figure $8(\mathrm{~b})$ ). In addition, these inclusions show a total homogenization to liquid at temperatures between 320 and $408^{\circ} \mathrm{C}$ (Figure 8(a)), with the calculated densities of 0.56 to $0.76 \mathrm{~g} / \mathrm{cm}^{3}$ (Table 1 ).
5.2.2. Middle Stage. Middle stage quartz crystals mainly contain C-, W-, and PC-type fluid inclusions, with C-type FIs being most abundant. The solid $\mathrm{CO}_{2}$ of the $\mathrm{C}$-type FIs yielded the melting temperatures $\left(T_{\mathrm{m}-\mathrm{CO}_{2}}\right)$ of -60.3 to $-56.9^{\circ} \mathrm{C}$ (Figure $7(\mathrm{c})$ ), which are slightly lower than the triple point of pure $\mathrm{CO}_{2}\left(-56.6^{\circ} \mathrm{C}\right)$, suggesting possible presence of minor amounts of other gases such as $\mathrm{CH}_{4}$, which were actually detected using Raman spectroscopy (Figure 9(d)). The $\mathrm{CO}_{2}$ clathrate was melted at the temperatures of 3.1 to $9.6^{\circ} \mathrm{C}$, with corresponding salinities range from 0.8 to $11.8 \mathrm{wt} . \%$ $\mathrm{NaCl}$ equivalent (Figure $8(\mathrm{~d})$ ). $\mathrm{CO}_{2}$ generally homogenized to the liquid phase and $\mathrm{T}_{\mathrm{h}-\mathrm{CO}_{2}}$ range from 18.7 to $30.8^{\circ} \mathrm{C}$ (Figure $7(\mathrm{~d})$ ). The densities of the $\mathrm{CO}_{2}$ phase are 0.54 to $0.79 \mathrm{~g} / \mathrm{cm}^{3}$, and the densities of the bulk inclusions are 0.70 to $0.95 \mathrm{~g} / \mathrm{cm}^{3}$ (Table 1 ). The C-type FIs are totally homogenized to liquid or vapour at 229 to $327^{\circ} \mathrm{C}$ (Figure 8(c)). For PC-type FIs, final melting to liquid was observed during heating process, with $T_{\mathrm{m}-\mathrm{CO}_{2}}$ ranging from -59.3 to $-56.9^{\circ} \mathrm{C}$ (Figure $7(\mathrm{c})$ ). Homogenization (to liquid) temperatures of $\mathrm{CO}_{2}\left(T_{\mathrm{h}-\mathrm{CO}_{2}}\right)$ vary from 17.1 to $28.7^{\circ} \mathrm{C}$ (Figure $7(\mathrm{~d})$ ), corresponding to densities of 0.64 to $0.80 \mathrm{~g} / \mathrm{cm}^{3}$ (Table 1 ). W-type FIs in the middle stage quartz have final ice melting temperatures of -8.6 to $-0.3^{\circ} \mathrm{C}$ and salinities of 0.5 to $12.4 \mathrm{wt} . \% \mathrm{NaCl}$ equivalent (Figure $8(\mathrm{~d})$ ). They homogenized to liquid at 201 to $329^{\circ} \mathrm{C}$ (Figure $8(\mathrm{c})$ ) with the densities of 0.75 to $0.95 \mathrm{~g} / \mathrm{cm}^{3}$.

5.2.3. Late Stage. Only W-type FIs are present in quartzcarbonate veins and veinlets in this stage. Their $T_{\mathrm{m} \text {-ice }}$ range from -3.9 to $-0.2^{\circ} \mathrm{C}$, corresponding to salinities of 0.4 to $6.3 \mathrm{wt} . \% \mathrm{NaCl}$ equivalent (Figure $8(\mathrm{f})$ ). They are totally homogenized to liquid at 134 to $227^{\circ} \mathrm{C}$ (Figure $8(\mathrm{e})$ ), and their calculated densities are 0.85 to $0.96 \mathrm{~g} / \mathrm{cm}^{3}$.

5.3. Raman Spectroscopy Analysis. Representative fluid inclusions were measured with laser Raman spectroscopy to determine their gas compositions (Figure 9). The results show that the vapour phase of PC-type and C-type FIs in the early stage was dominated by $\mathrm{CO}_{2}$ (Figures 9(a) and 9(b)), and the liquid phase of C-type inclusions has large amount of water (Figure 9(b)). The PC-type and C-type FIs of the early stage show well-defined $\mathrm{CO}_{2}$ peaks (Figures 9(a) and 9(b)). The PC-type FIs of the middle stage show well-defined $\mathrm{CO}_{2}$ peaks and slightly $\mathrm{CH}_{4}$ peaks (Figure 9(c)), and the C-type FIs from the middle stage contain a vapour phase of $\mathrm{CO}_{2}$ with minor amounts of $\mathrm{CH}_{4}$ and a liquid phase with a large amount of water (Figures 9(d) and 9(e)). Both vapour and liquid phases of the W-type FIs in the late stage are dominated by water; other gas phases were barely found (Figure 9(f)). The results are also consistent with previous gas analyses of crashed of groups of fluid inclusions [26] that the gas compositions of fluid inclusions are dominated by $\mathrm{CO}_{2}$, followed by trace amount of $\mathrm{CH}_{4}, \mathrm{CO}, \mathrm{H}_{2}$, and $\mathrm{N}_{2}$. No $\mathrm{CO}, \mathrm{H}_{2}$, or $\mathrm{N}_{2}$ were detected by laser Raman in this study which might be due to their low content in the vapour phase of the fluid inclusions.

5.4. H-O-C Isotope Data. The hydrogen and oxygen isotope data obtained from the Liyuan gold deposit are listed in Table 2. Quartz separates have $\delta^{18} \mathrm{O}_{\mathrm{m}}$ values of 10.1 to $13.2 \%$, 


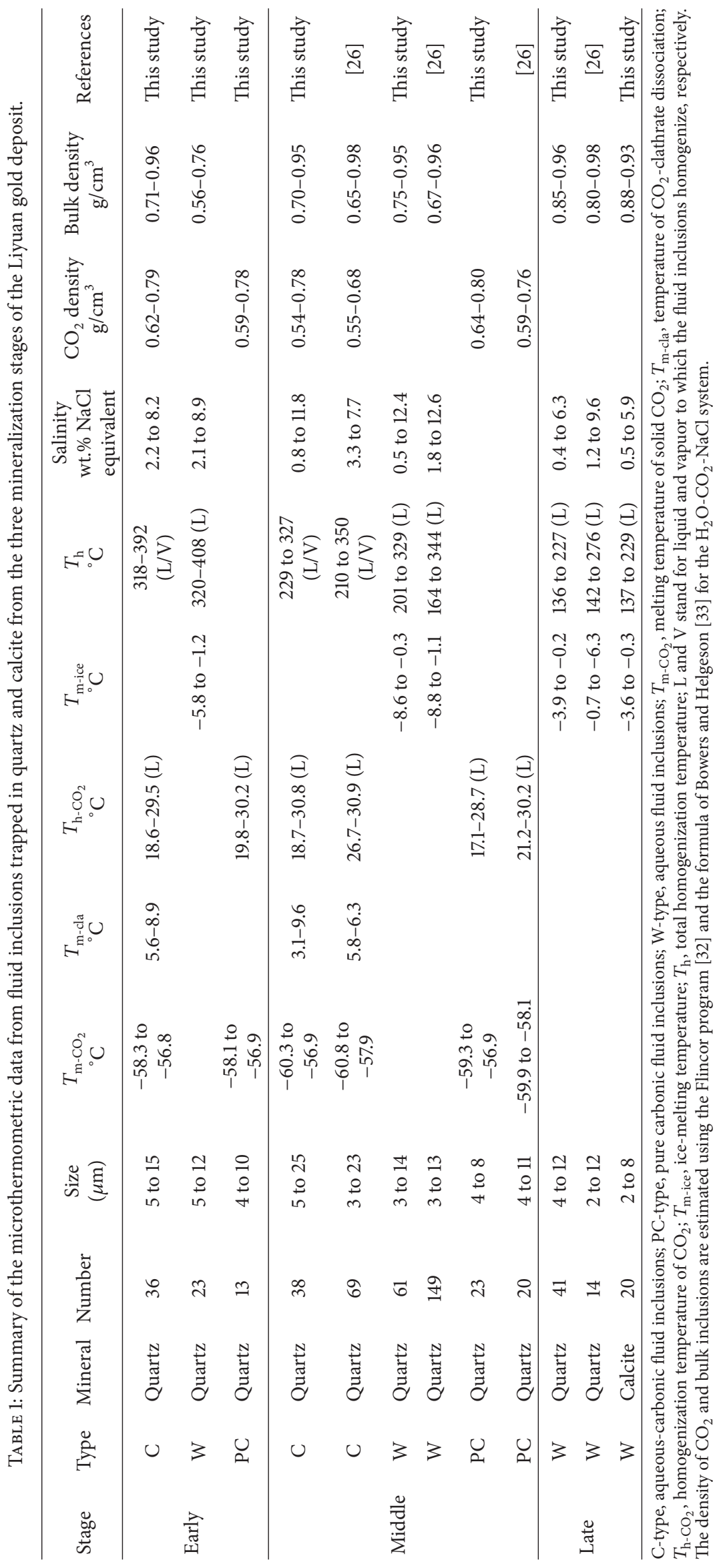




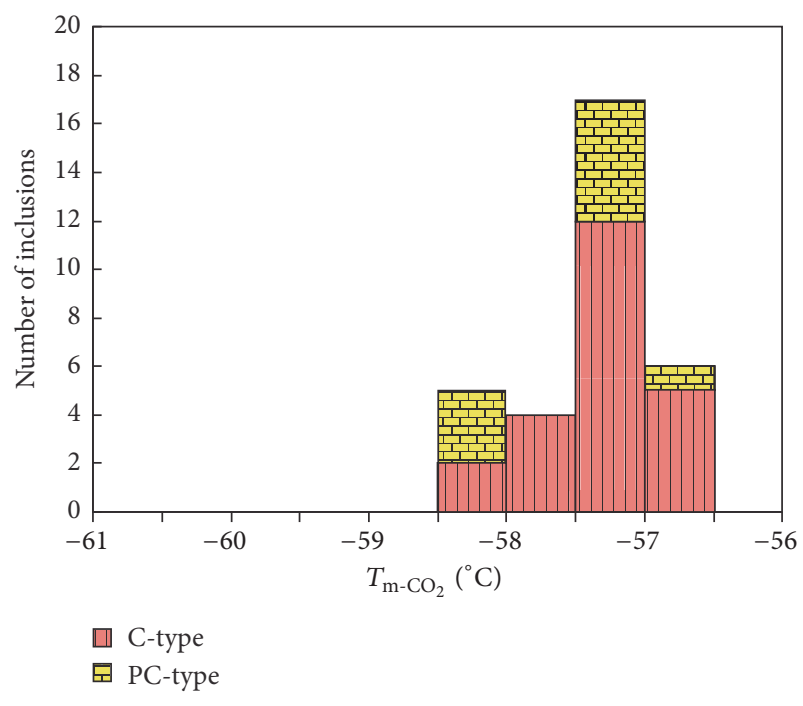

(a)

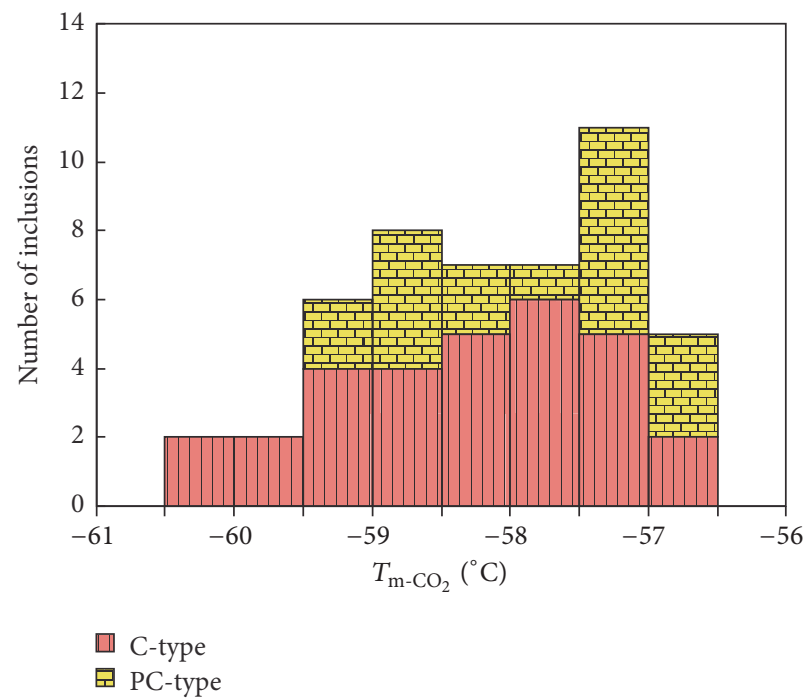

(c)

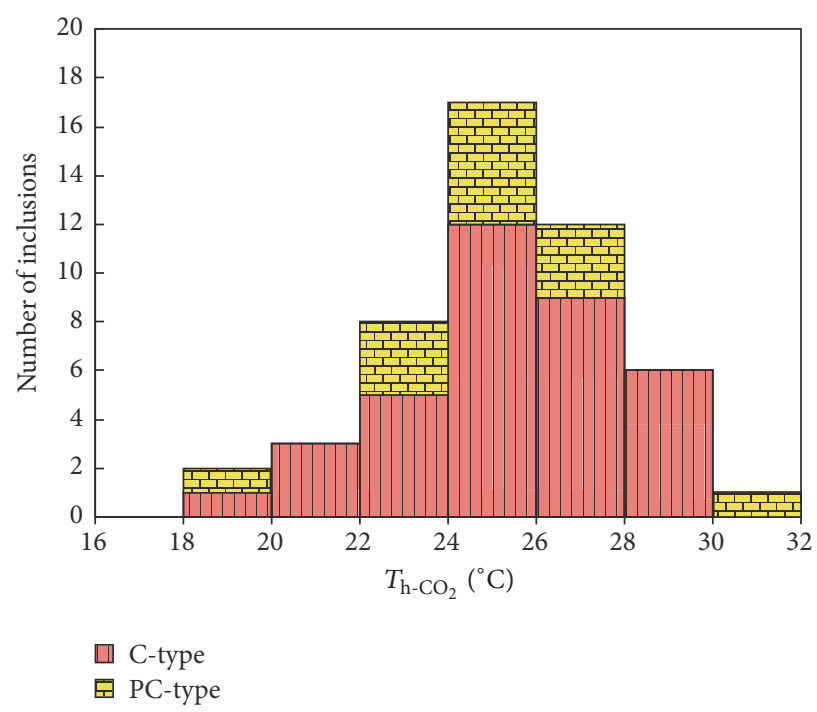

(b)

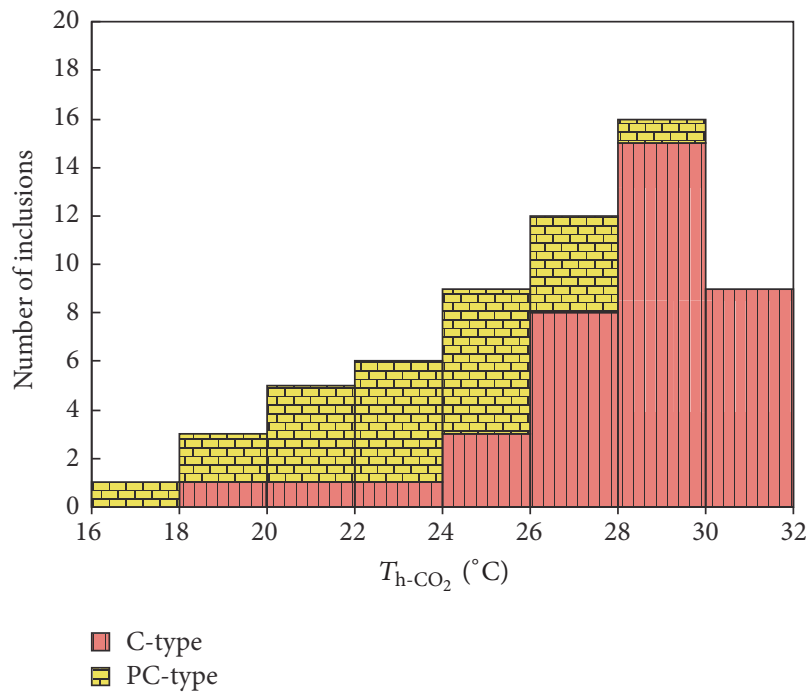

(d)

Figure 7: Histograms of $\mathrm{CO}_{2}$ melting temperatures $\left(T_{\mathrm{m}-\mathrm{CO}_{2}}\right)$ of $\mathrm{CO}_{2}$-bearing fluid inclusions in the early stage (a) and middle stage (c) quartz grains and $\mathrm{CO}_{2}$ homogenization temperature of $\mathrm{CO}_{2}$-bearing fluid inclusions in the early stage (b) and middle stage (d) quartz or calcite grains.

with an average of $12.0 \%$, whereas fluid inclusion water extracted from quartz has $\delta \mathrm{D}$ values of -87 to $-66 \%$, with an average of $-80 \%$. $\mathrm{CO}_{2}$ in fluid inclusions have a narrow $\delta^{13} \mathrm{C}_{\mathrm{CO}_{2}}$ range of -8.9 to $-7.1 \%$, with an average of $-7.9 \%$. Oxygen isotopic compositions of hydrothermal water were calculated according to the measured $\delta^{18} \mathrm{O}$ values of quartz and the mean value of the total homogenization temperatures of fluid inclusions from the same samples plus pressurecorrected temperature as discussed below. The calculations yield $\delta^{18} \mathrm{O}_{\mathrm{w}}$ of 2.2 to $9.5 \%$ for the ore-forming fluids, with an average value of $5.8 \%$.

\section{Discussion}

6.1. Fluid Immiscibility and Pressure Estimations. In the Liyuan deposit, abundant primary W-type, C-type, and
PC-type FIs coexist in a given cluster in both early and middle stage quartz grains (Figures $6(\mathrm{i})-6(\mathrm{k})$ ). In spite of postentrapment modifications (such as subsequent necking during annealing of microfractures) which might cause coexistence of the $\mathrm{W}$-type, C-type, and PC-type FIs in the same sample [65, 66], fluid inclusions were studied in samples that are absence of abundant of secondary inclusions trails and exhibiting no evidence of postentrapment modification (i.e., stretching, leaking, and necking down; e.g., [67]). All the fluid inclusions selected for microthermometry and laser Raman spectroscopy are primary in origin, which generally occurred in undeformed quartz grains and with regular shapes.

Fluid immiscibility is commonly associated with gold and sulfide deposition in a variety of hydrothermal deposits, including the Yanzhaiyu gold deposit in Xiaoqinling [68], the 


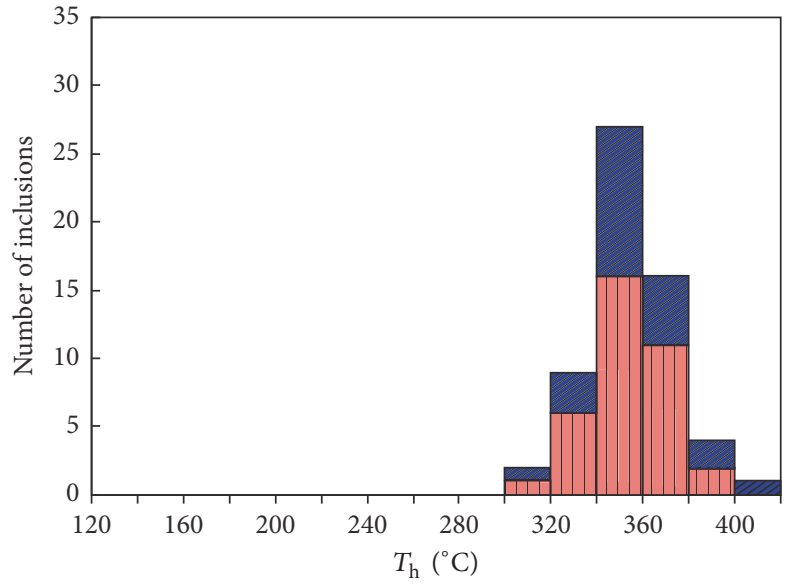

ㄴ C-type

W-type

(a)

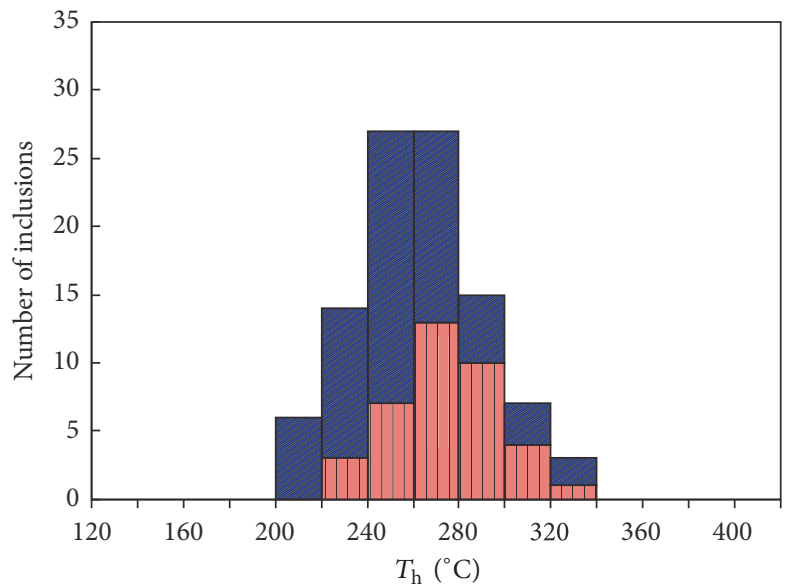

(1) C-type

W-type

(c)

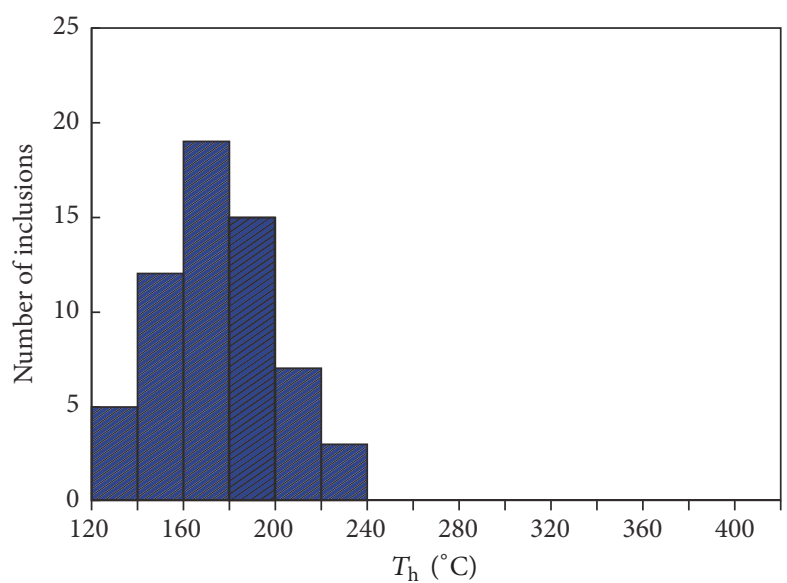

W-type

(e)

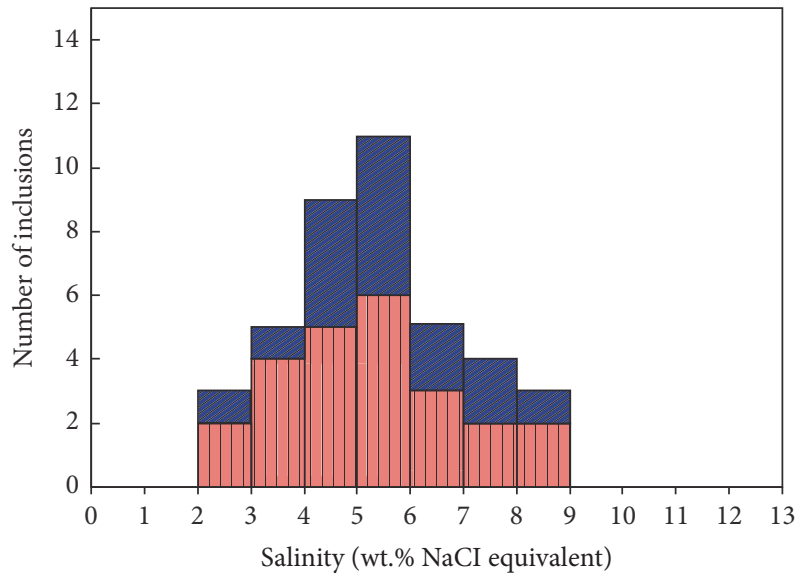

C-type

W-type

(b)

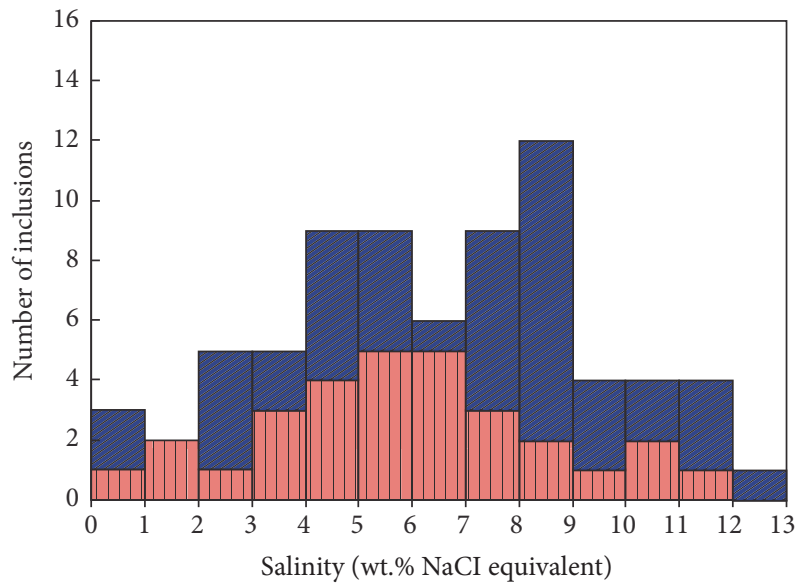

1 C-type

W-type

(d)

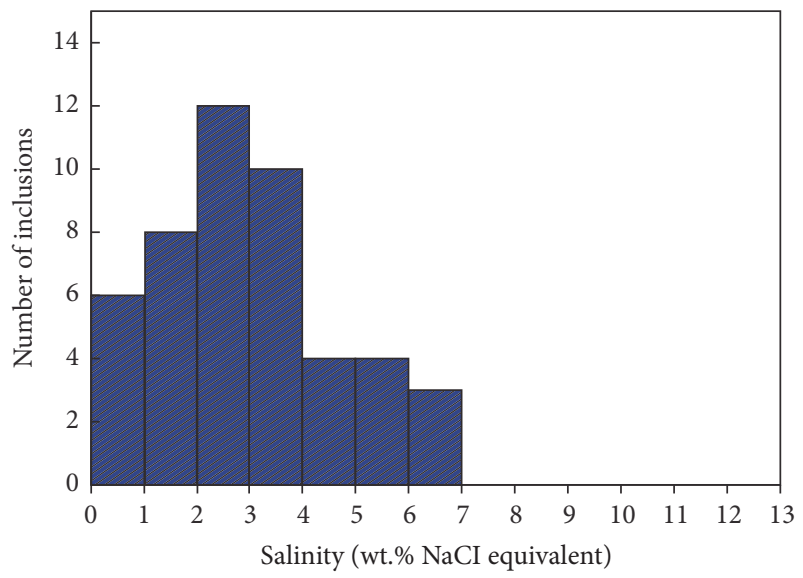

W-type

(f)

Figure 8: Histograms of total homogenization temperatures $\left(T_{\mathrm{h}}\right)$ and salinities of C-type and W-type fluid inclusions in the early stage (a, b), middle stage (c, d), and W-type fluid inclusions in the late stage (e, f). 


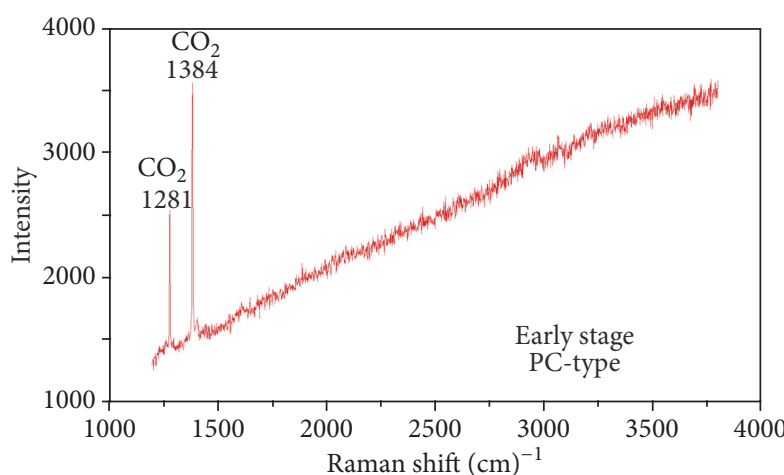

(a)

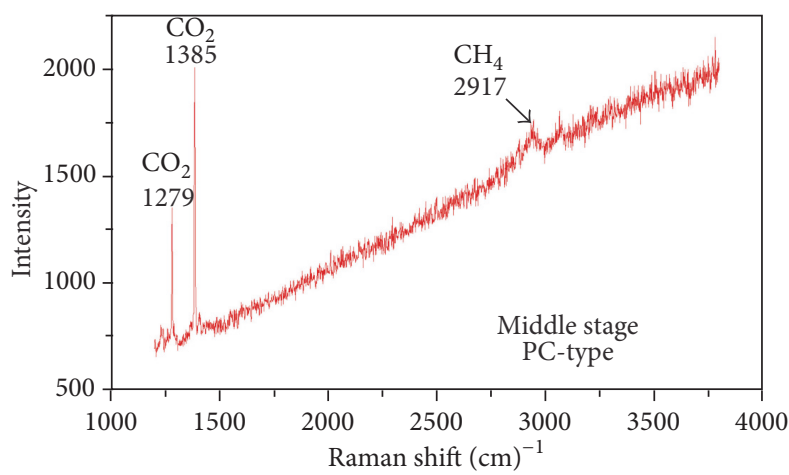

(c)

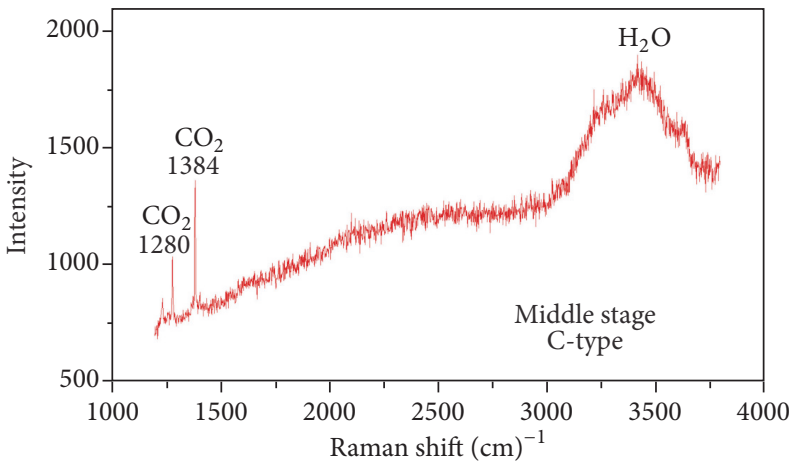

(e)

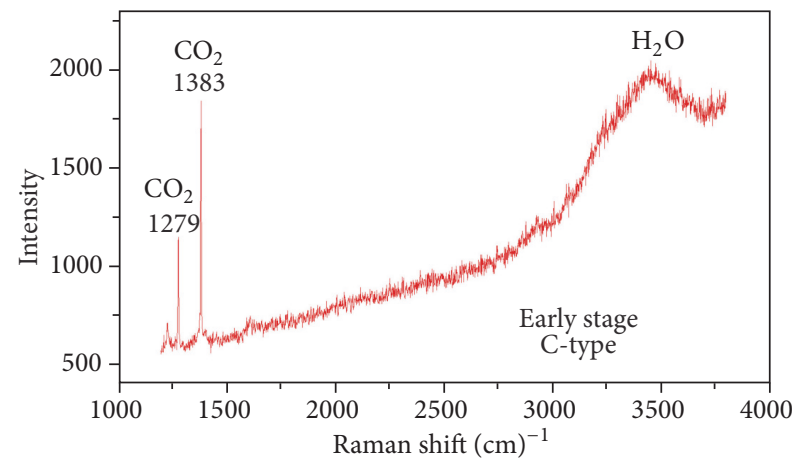

(b)

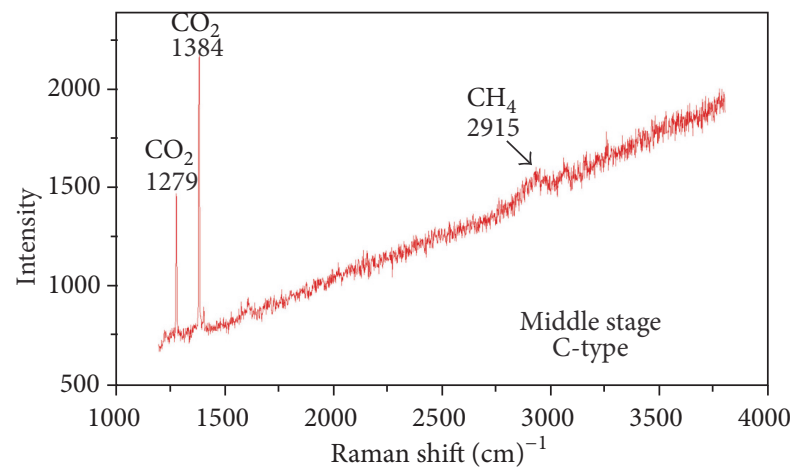

(d)

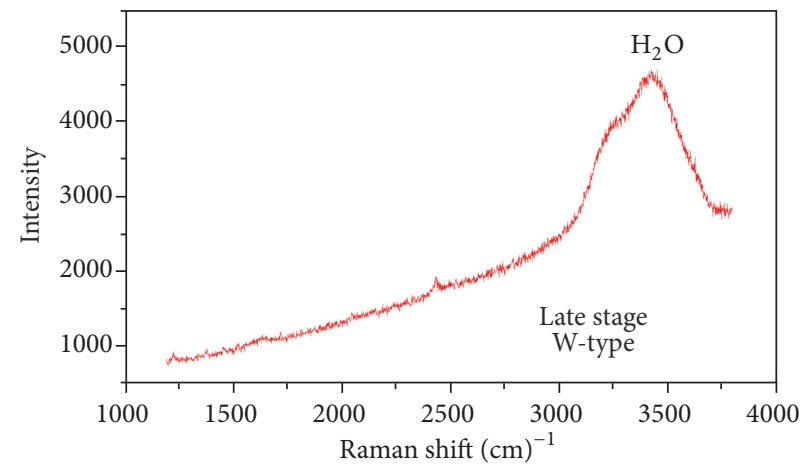

(f)

Figure 9: Representative Raman spectra of fluid inclusions in the Liyuan gold deposit. (a) $\mathrm{CO}_{2}$ spectra of vapour in PC-type inclusions of the early stage; (b) $\mathrm{H}_{2} \mathrm{O}$ and $\mathrm{CO}_{2}$ spectra of vapour in C-type inclusions of the early stage; (c) $\mathrm{CO}_{2}$ and $\mathrm{CH}_{4}$ spectra of vapour in PC-type inclusions of the middle stage; (d) $\mathrm{CO}_{2}$ and $\mathrm{CH}_{4}$ spectra of vapour in C-type inclusions of the middle stage; (e) $\mathrm{CO}_{2}$ and $\mathrm{H}_{2} \mathrm{O}$ spectra of vapour in C-type inclusions of the middle stage; (f) $\mathrm{H}_{2} \mathrm{O}$ spectra of vapour in $\mathrm{W}$-type inclusions of the middle stage.

Xincheng [69] and Taishang [70] gold deposits in Jiaiodong, and the Jinman $\mathrm{Cu}$ deposit in Yunnan, China [71]. Ramboz et al. [72] defined four criteria which can be used to recognize fluid immiscibility, including (1) the contemporaneous trapping of different types of fluid inclusions; (2) trapped fluid inclusions with varying scattered degree of filling; (3) two completely different modes of total homogenization of the liquid-rich $(\mathrm{L}+\mathrm{V} \rightarrow \mathrm{L})$ and vapour-rich $(\mathrm{L}+\mathrm{V} \rightarrow \mathrm{V})$ fluid inclusions within the same range of temperature; (4) the relative concentration of chemical components in the liquid and vapour phase which should be appropriate to equilibrium fractionation at total homogenization.
Evidences for fluid immiscibility at the Liyuan gold deposit include the following:

(1) There are three different types of fluid inclusions, including aqueous-carbonic (C-type), pure carbonic (PCtype), and aqueous fluid inclusions (W-type), in the Liyuan gold deposit. They coexist with each other in the early and middle stages.

(2) C-type FIs have the variable phase ratios and degree of filling changed continuously from $10 \mathrm{vol}$ \% (Figure 6(a)) to 90 vol.\% (Figure 6(b)).

(3) In the early and middle stages, $\mathrm{W}$-type and C-type FIs have similar total homogeneous temperatures (Figures 
TABLE 2: The $\delta^{18} \mathrm{O}_{\mathrm{m}}, \delta^{18} \mathrm{O}_{\mathrm{w}}$, and $\delta \mathrm{D}$ data (\%o) of the Liyuan gold deposit.

\begin{tabular}{lccccccc}
\hline Sample & Stage & $\delta^{18} \mathrm{O}_{\mathrm{m}}$ & $\delta^{18} \mathrm{O}_{\mathrm{w}}$ & $\delta \mathrm{D}$ & $\delta^{13} \mathrm{C}_{\mathrm{CO}_{2}}$ & $T_{\mathrm{h}}\left({ }^{\circ} \mathrm{C}\right)$ & $\mathrm{T}(\mathrm{p}$ correction $)\left({ }^{\circ} \mathrm{C}\right)$ \\
\hline LY13-1-6 & Early & 12.1 & 9.5 & -66 & -7.1 & 356 & 120 \\
LY13-2-1 & Middle & 10.1 & 4.3 & -83 & -8.9 & 262 & 70 \\
LY13-2-11 & Middle & 12.7 & 7.1 & -85 & -7.6 & 271 & 70 \\
15LYD-12 & Late & 13.2 & 2.2 & -87 & & 182 & 30 \\
\hline
\end{tabular}

$\delta^{18} \mathrm{O}_{\mathrm{m}}$, measured $\delta^{18} \mathrm{O}$ value of quartz; $\delta^{18} \mathrm{O}_{\mathrm{w}}$ value of ore-forming fluids in equilibrium with quartz is calculated according to the equation of 1000 $\ln \alpha_{\text {quartz- } \mathrm{H}_{2} \mathrm{O}}=3.38 \times 10^{6} \mathrm{~T}^{-2}-3.40$ reported by Clayton et al. [34]. The temperatures used in calculation are the mean values of the homogenization temperatures from the same quartz samples plus pressure corrected temperatures; that is, $T=T_{\mathrm{h}}+T$ (P correction); $\delta^{13} \mathrm{C}_{\mathrm{CO}_{2}}$ values refer to $\mathrm{CO}_{2}$ released from fluid inclusions.

8(a) and 8(c)). C-type FIs show two completely different modes of total homogenization of the liquid-rich $(\mathrm{L}+\mathrm{V} \rightarrow$ $\mathrm{L})$ and vapour-rich $(\mathrm{L}+\mathrm{V} \rightarrow \mathrm{V})$ fluid inclusions within approximately the same temperature range (Table 1; Figures 7 and 8). PC-type FIs share similar range of $\mathrm{CO}_{2}$ homogenization temperatures with the C-type FIs (Table 1; Figure 7), indicating that they were trapped coevally and could be the same $\mathrm{H}_{2} \mathrm{O}-\mathrm{CO}_{2}-\mathrm{NaCl}$ solution. PC-type FIs probably represent an unmixing $\mathrm{CO}_{2}$-rich endmember. Although a water phase is not visible, the PC-type inclusions may contain up to $15 \mathrm{vol}$.\% water since the water prefers to adhere to the inclusion walls as a thin film [72-74].

(4) C-type FIs show slightly lower salinities (median values of 4.26 and 5.33 wt.\% $\mathrm{NaCl}$ equivalent in the early and middle stages, resp.) than the W-type FIs (median values of 5.86 and $8.55 \mathrm{wt} \% \mathrm{NaCl}$ equivalent in the early and middle stages, resp.) (Figures $8(\mathrm{~b})$ and $8(\mathrm{~d})$ ), which is consistent with phase separation [75].

Therefore, fluid immiscibility is a likely explanation for characteristics of fluid inclusions in the early and middle stages.

Trapping pressure-temperature estimation can be made using isochores determined from the fluid inclusions [76]. When immiscibility occurs, a homogenous fluid splits into a more dense and saline phase endmember and a volatilerich phase endmember $[77,78]$. Trapping pressure can be approximated from endmember inclusions trapped under immiscible conditions [74, 77-79]. Based on our study, immiscible entrapment is interpreted to have occurred at the early and middle stages at Liyuan. Therefore, we selected Ctype fluid inclusions in the early and middle stages with the low and high $X_{\mathrm{CO}_{2}}$ contents to estimate trapping pressures. Isochores were calculated based on the $\mathrm{H}_{2} \mathrm{O}-\mathrm{CO}_{2}-\mathrm{NaCl}$ system using the formula of Bowers and Helgeson [33] and Flincor program $[10,33,80]$.

Given that the total homogenization temperatures of fluid inclusions can be only used to provide minimum formation temperature for the quartz veins/veinlets, the pressure estimates are always difficult [81]. Therefore, we use the same logic as used by Fan et al. [82] to revise the treatment of pressure and temperature. Measured total homogenization temperatures are set as $X$, and using these values as minimum temperature, a preliminary minimum pressure $P 1$ can be obtained from isochores. Using this value of $P 1$, trapping temperatures could be used as $X+Z$. This revised trapping

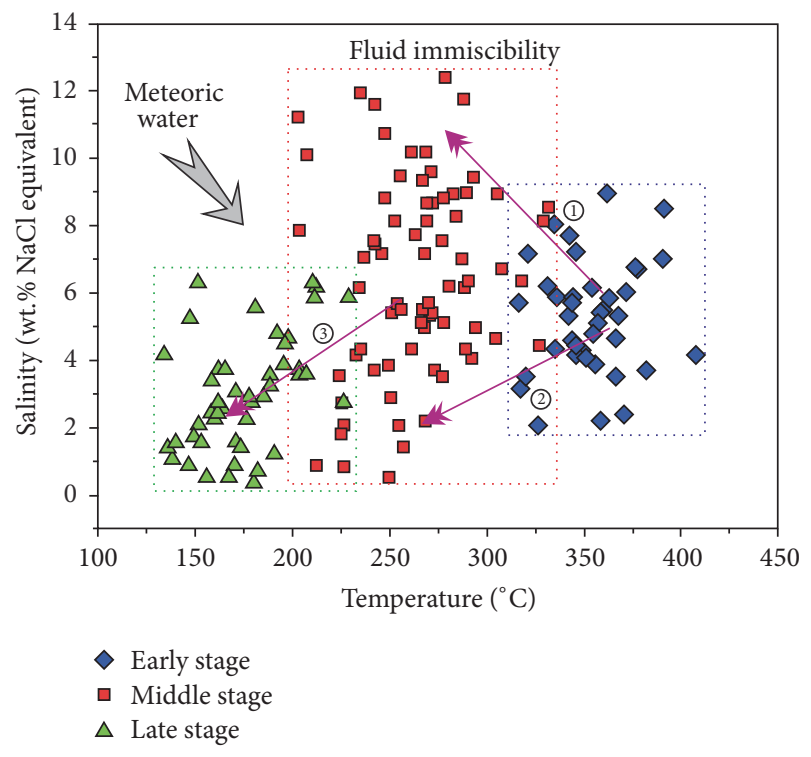

FIGURE 10: Salinity versus total homogenization temperature plot of the fluid inclusions, showing fluid evolution in the Liyuan gold deposit. Three purple arrows marked as (1), (2), and (3) represent the fluid evolution tendency from early to late stages. The arrows (1) and (2) mean that the FIs have wider salinities range from early to middle stage due to the fluid immiscibility. The arrow (3) represents that the temperature and salinities both decrease from middle to late stages.

temperature could be used to calculate a more accurate pressure of $P 2$.

In the case of Liyuan, since the total homogenization temperatures and bulk densities of C-type FIs have variable ranges, upper and lower quartiles are used to better reflect the distribution of the data (e.g., [83]). For the C-type FIs in the early stage, upper and lower quartiles of homogenization temperatures are $343^{\circ} \mathrm{C}$ and $367^{\circ} \mathrm{C}$, respectively, and the associated C-type FIs with the low and high $X_{\mathrm{CO}_{2}}$ contents have bulk densities of $0.89 \mathrm{~g} / \mathrm{cm}^{3}$ and $0.77 \mathrm{~g} / \mathrm{cm}^{3}$ (Figure 10). The preliminary pressure from Figure 11 is about $140 \mathrm{MPa}$ at $343^{\circ} \mathrm{C}$. The pressure correction at $140 \mathrm{MPa}$ is about $120^{\circ} \mathrm{C}$ [63]. Thus, the trapping temperatures for the early stage $\mathrm{C}$ type fluid inclusions are from 463 to $487^{\circ} \mathrm{C}$. The recalculated trapping pressure is 239 to $347 \mathrm{MPa}$ (Figure 11). In the middle stage, the upper and lower quartiles of total homogenization 


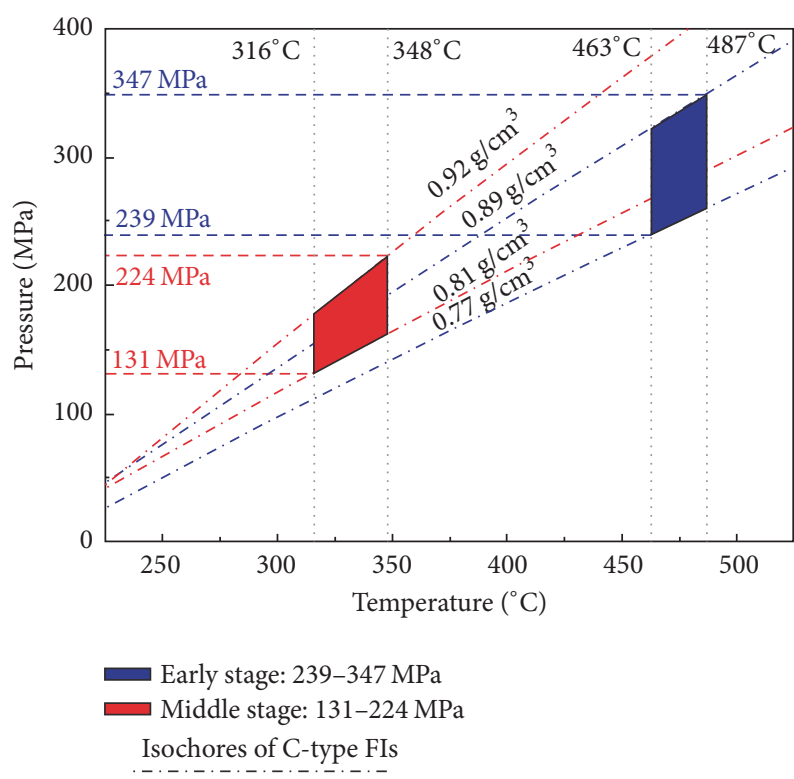

FIGURE 11: Pressure-temperature conditions for the early and middle stages in the Liyuan gold deposit.

temperatures of C-type FIs are 246 to $278^{\circ} \mathrm{C}$, respectively, and the associated C-type FIs with the low and high $X_{\mathrm{CO}_{2}}$ contents have bulk densities of $0.92 \mathrm{~g} / \mathrm{cm}^{3}$ and $0.81 \mathrm{~g} / \mathrm{cm}^{3}$. The preliminary minimum pressure from Figure 11 is about $70 \mathrm{MPa}$, and according to Roedder [63] the pressure correction at $70 \mathrm{MPa}$ is about $70^{\circ} \mathrm{C}$. Thus, the trapping temperatures for the C-type FIs from the middle stage are 316 to $348^{\circ} \mathrm{C}$. The recalculated trapping pressure for the C-type FIs is 131 to $224 \mathrm{MPa}$ (Figure 11).

The trapping pressures for the C-type FIs of early stage (239-347 MPa) are higher than those of middle stage (131-224 MPa), indicating a pressure decrease during the oreforming process. The variations of the trapping pressures might reflect fluctuations between hydrostatic and lithostatic conditions during fluid immiscibility [84], and this situation is common in orogenic gold deposits (e.g., [85-87]). In the Liyuan deposit, minor $\mathrm{CH}_{4}$ was found in the carbonic phase of the C-type and PC-type FIs in the middle stage. Additional volatile components such as $\mathrm{CH}_{4}$ could expand the temperature and pressure range of fluid immiscibility and make the occurrence of fluid immiscibility much easier $[88,89]$. At Liyuan, we suggest that the fluid immiscibility was induced by pressure drop and temperature decrease, which could lower the $\mathrm{CO}_{2}$ solubility in the $\mathrm{H}_{2} \mathrm{O}-\mathrm{CO}_{2}-\mathrm{NaCl}$ system $[33,90]$, and the presence of $\mathrm{CH}_{4}$ in the middle stage could make the fluid immiscibility become easier.

6.2. Source of Ore-Forming Fluids. The oxygen isotopic compositions of the early and middle stages ore-forming fluids of the Liyuan deposit are similar to those of magmatic water or metamorphic water, but the hydrogen isotopes plot slightly below the magmatic water or metamorphic water fields, and the late stage fluids show both lower oxygen and hydrogen isotopic compositions than the magmatic water or metamorphic water in the $\delta \mathrm{D}$ vs $\delta^{18} \mathrm{O}$ diagram (Figure 12).

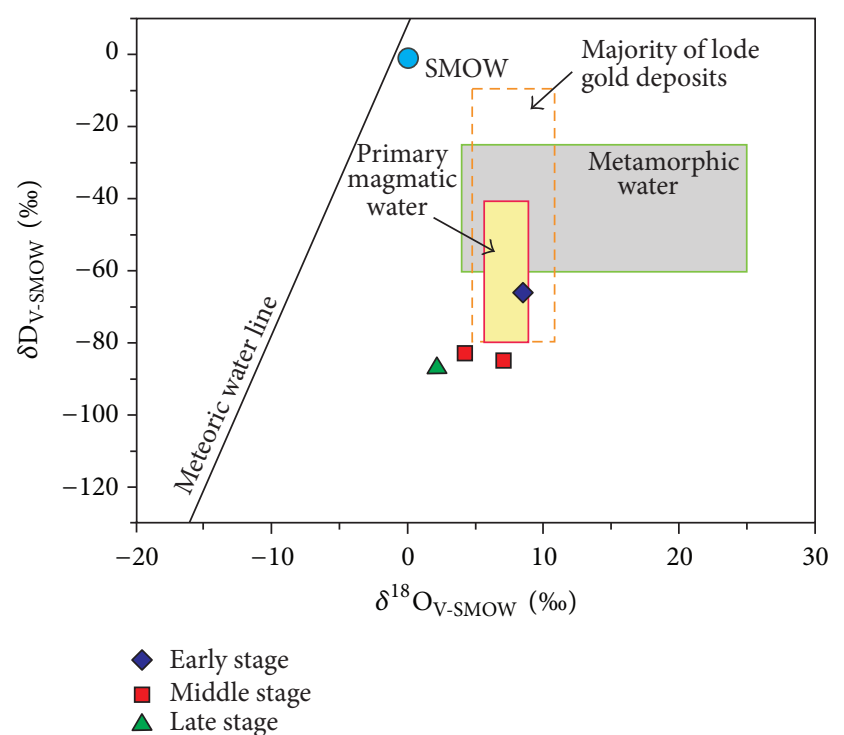

FIgURE 12: $\delta \mathrm{D}$ vs $\delta^{18} \mathrm{O}$ plot of the ore-forming fluids in the Liyuan gold deposit. Also shown are the isotopic fields for common metamorphic and primary magmatic water [30]. The field for orogenic gold deposit revised after Goldfarb et al. [31].

This feature suggests that the primary ore-forming fluids of the Liyuan gold deposit were genetically akin to either magmatic water or metamorphic water. The calculated $\delta^{18} \mathrm{O}_{\mathrm{w}}$ values of ore-forming fluids of the three hydrothermal stages show a decrease from $9.5 \%$ o to $5.7 \%$ and to $2.2 \%$, and that from the late stage are significantly lighter than those of primary magmatic water (5 to $10 \%$, [91]), suggesting an increasing amount of meteoric water mixing with the magmatic or metamorphic fluids, especially in the late stage. The lower $\delta \mathrm{D}$ values may also attribute to the existence of $\mathrm{CH}_{4}$ in the ore-forming fluids. The ore-forming fluids at Liyuan have $\delta^{13} \mathrm{C}_{\mathrm{CO}_{2}}$ values of -8.9 to $-7.1 \%$, with an average of $-7.9 \%$, which are similar to or slightly lower than those of average mantle value ( -7 to $-5 \%$, $[92,93])$, indicating that the carbon in the Liyuan deposit was likely derived from a deep magmatic source. In addition, the $\delta^{13} \mathrm{C}_{\mathrm{CO}_{2}}$ values are slightly lower than those of average mantle and might be affected by an isotopic fractionation due to chemical reactions such as carbonate decomposition or contaminations of minor $\mathrm{CH}_{4}$ gas related to metamorphism [94].

The characteristics of the ore-forming fluids, such as moderate to low temperature, low salinity, and high $\mathrm{CO}_{2}$ content in the fluid inclusions, are typical of the majority of orogenic gold deposits worldwide (e.g., [1, 2, 4, 95, 96]). Although many of these deposits have been attributed to be formed by metamorphic fluids (e.g., [97, 98]), models of magmatic fluid origin with admixing with local meteoric water have also been proposed in many orogenic gold deposits (e.g., [82, 99-102]). In the case of the Liyuan gold deposit, given that the late Mesozoic age of gold mineralization in the northern TM region is over 2 billion years younger than the age of metamorphic rocks, the regional metamorphic fluids associated with those Precambrian rocks are not a viable source, whereas the deep-seated magmatic water would have 
generated the ore-forming fluids, although currently we did not found any granite body at Liyuan but a concealed granite body at greater depths is possible according to recent geophysical survey (personal communications) although further work is still needed to test this hypothesis.

6.3. Fluid Evolution and Gold Deposition. Fluid inclusion microthermometry and laser Raman spectroscopy indicate dominant C-type FIs and subordinate W- and PC-type FIs are developed in the early stage quartz. In this stage, ore-forming fluids belong to $\mathrm{H}_{2} \mathrm{O}-\mathrm{CO}_{2}-\mathrm{NaCl}$ system, which featured by moderate temperatures $\left(318\right.$ to $\left.408^{\circ} \mathrm{C}\right), \mathrm{CO}_{2}$-bearing, and low salinity (2.1 to $8.9 \mathrm{wt} \% \mathrm{NaCl}$ equivalent). In the middle stage, C-type FIs are dominant, and W- and PC-type FIs are also present. The ore-forming fluids change a little and belong to $\mathrm{H}_{2} \mathrm{O}-\mathrm{CO}_{2}-\mathrm{NaCl} \pm \mathrm{CH}_{4}$ system, which featured by moderate temperature $\left(201\right.$ to $329^{\circ} \mathrm{C}$ ), lower $\mathrm{CO}_{2}$ with minor $\mathrm{CH}_{4}$, but higher salinity ( 0.5 to $12.4 \mathrm{wt} . \% \mathrm{NaCl}$ equivalent), which is consistent with fluid immiscibility in this stage. During the phase separation, salt is preferentially fractionated into the aqueous phase, which leads to the result that the salinities of W-type FIs ( 0.5 to 12.4 wt.\% $\mathrm{NaCl}$ equivalent, with a median value of 8.55 wt.\% $\mathrm{NaCl}$ equivalent ) were slightly higher than those of C-type FIs ( 0.8 to 11.8 wt.\% $\mathrm{NaCl}$ equivalent, with an median value of 5.33 wt. $\% \mathrm{NaCl}$ equivalent) [75]. In the late stage, the ore-forming fluids finally evolved into a low temperature $\left(136\right.$ to $229^{\circ} \mathrm{C}$ ), low salinity ( 0.4 to $6.3 \mathrm{wt} . \%$ $\mathrm{NaCl}$ equivalent), and $\mathrm{CO}_{2}$-poor $\mathrm{H}_{2} \mathrm{O}-\mathrm{NaCl}$ system which is similar to the fluids sourced from meteoric water and that is also supported by the hydrogen-oxygen isotope data (Figure 12).

As shown above, the gold orebodies of the Liyuan deposit are mainly hosted within the Archaean gneisses, and plagioclase, hornblende, and ilmenite are very common in the gneisses, and the quartz, K-feldspar, titanite, and chlorite are the typical alteration minerals that are well developed in the altered gneisses [26]. The minor $\mathrm{CH}_{4}$ found in the C-type and PC-type FIs in the middle stage could be the product of the following reactions [103]:

$$
\begin{aligned}
& \mathrm{Ca}_{2}(\mathrm{Mg}, \mathrm{Fe})_{4} \mathrm{Al}\left(\mathrm{Si}_{7} \mathrm{AlO}_{22}\right)(\mathrm{OH})_{2} \text { (hornblende) } \\
& +\mathrm{FeTiO}_{3} \text { (ilmenite) }+\mathrm{CaAl}_{2} \mathrm{Si}_{2} \mathrm{O}_{8} \text { (plagioclase) } \\
& \quad+\mathrm{H}_{2} \mathrm{O} \longrightarrow \\
& \mathrm{CaTiSiO}_{5} \text { (titanite) } \\
& \quad+(\mathrm{Mg}, \mathrm{Fe}, \mathrm{Al})_{9}\left((\mathrm{Si}, \mathrm{Al})_{4} \mathrm{O}_{10}\right)(\mathrm{OH})_{8} \text { (chlorite) } \\
& +\mathrm{KAlSi}_{3} \mathrm{O}_{8}(\mathrm{~K} \text {-feldspar })+\mathrm{SiO}_{2}(\text { quartz })+\mathrm{H}_{2} \\
& \mathrm{CO}_{2}+4 \mathrm{H}_{2} \longrightarrow \mathrm{CH}_{4}+2 \mathrm{H}_{2} \mathrm{O}
\end{aligned}
$$

Therefore, the presence of $\mathrm{CH}_{4}$ in the middle stage was most likely related to the water-rock interaction between oreforming fluids and the wall rocks at Liyuan.

Gold is predominantly transported as gold chloride $\left(\mathrm{AuCl}^{2-}\right)$ and gold bisulfide complexes $\left(\mathrm{Au}(\mathrm{HS})_{2}{ }^{-}\right)$in hydrothermal solutions [104-107]. Commonly, the $\mathrm{AuCl}^{2-}$ complexes are predominant in near-neutral to weakly alkaline, high salinity, and $\mathrm{H}_{2} \mathrm{~S}$-poor ore fluids at high temperatures $\left(>400^{\circ} \mathrm{C},[108]\right)$, whereas for near-neutral to weakly acidic $\mathrm{pH}$ in sulfur-bearing solutions and at relatively low temperatures $\left(<400^{\circ} \mathrm{C}\right)$, the $\mathrm{Au}(\mathrm{HS})_{2}{ }^{-}$complexes play a more important role to transport gold $[109,110]$. The K-feldsparsericite mineral assemblages, developed not only in the alteration zone but also in the quartz vein, indicate that the ore-forming fluids of the Liyuan gold deposit are nearneutral to weakly acidic $(\mathrm{pH}=5.2-6.8,[69,111])$. Taking into consideration that the ore-forming fluids were rich in $\mathrm{CO}_{2}$ at $201-408^{\circ} \mathrm{C}$, it is likely that the gold was transported by $\mathrm{Au}(\mathrm{HS})_{2}{ }^{-}$complexes in the ore-forming fluids, which is also consistent with the fact that gold is usually accompanied with sulfides (especially pyrite, Figures 4(h) and 4(i)). Thus, gold deposition at Liyuan probably is related to the breakdown of gold bisulfide complexes $\left(\mathrm{Au}(\mathrm{HS})_{2}{ }^{-}\right.$). Previous experimental and theoretical studies have shown that when temperature is below $400^{\circ} \mathrm{C}$, a decrease in temperature at consistent fluid composition would enhance $\mathrm{Au}(\mathrm{HS})_{2}{ }^{-}$solubility [112]. Therefore, simple cooling of ore-forming fluids from early to middle stage is not an effective gold deposition mechanism for the Liyuan deposit. However, $\mathrm{H}_{2} \mathrm{~S}$ loss and a decrease in $\mathrm{HS}^{-}$activity could decrease solubility effectively [88].

Fluid immiscibility and water-rock interaction are the two possible mechanisms that could result in the $\mathrm{H}_{2} \mathrm{~S}$ loss of the ore-forming fluids [113-116]. In the case of Liyuan, primary fluid inclusions in quartz from both early and middle stages show evidence of fluid immiscibility. However, the early stage quartz veins/veinlets only contain minor pyrite and trace amount of gold. Thus, the fluid immiscibility might not play an important role of the gold deposition at Liyuan. Given that gold is associated with widespread pyrite-sericitequartz alteration in the Liyuan deposit (Figure 3) and the close association of gold minerals and sulfides (especially pyrite, Figures $4(\mathrm{~h})$ and $4(\mathrm{i})$ ), the reaction between orebearing fluids and iron-bearing wall rocks to form pyrite is probably a more effective means of decreasing the $\mathrm{H}_{2} \mathrm{~S}$ concentration and leads to gold deposition [113].

6.4. Comparison to Orogenic Gold Deposits. As mentioned above, many geological and geochemical features of the Liyuan gold deposit are consistent with typical orogenic gold deposits worldwide $[5,86,117]$. These features include the following:

(1) The orebodies which are mainly hosted in the Archean Fuping Group metamorphic rocks and are structurally controlled by the NNE-trending faults.

(2) Multiple stages of mineralization of the disseminated and quartz vein and veinlet/stockworks ores.

(3) Sulfide mineral associations of dominantly pyrite, with minor sphalerite, galena, and chalcopyrite.

(4) Hydrothermal alteration characterized by silicic, Kfeldspar, sericite, chlorite, and carbonate alterations.

(5) The ore-forming fluids which were low to moderate temperature, $\mathrm{H}_{2} \mathrm{O}-\mathrm{CO}_{2}-\mathrm{NaCl}-\left(\mathrm{CH}_{4}\right)$ system with low salinity, and the fluid which was rich in $\mathrm{CO}_{2}$. 
(6) The fluids transformed from $\mathrm{CO}_{2}$-rich ore-forming fluids to $\mathrm{CO}_{2}$-poor meteoric water during fluid evolution.

These features supported the fact that the Liyuan deposit could be classified as an orogenic type gold deposit. Although hosted in the Archean basement rocks, the gold deposits in the TM region of central NCC are most likely Early Cretaceous in age. For example, quartz separates from the auriferous quartz veins hosted in the Precambrian metamorphic rocks in the Shihu and Yixingzhai gold deposits in the same region yielded ${ }^{40} \mathrm{Ar}^{39} \mathrm{Ar}$ ages of $141 \pm 4 \mathrm{Ma}$ [22] and $131 \pm 3 \mathrm{Ma}$ [118], respectively. These ages preclude a genetic relationship between gold mineralization and the Neoarchean metamorphism in the central NCC [40-43] but may suggest that the Liyuan deposit was formed during the Yanshanian magmatism although further direct age data are needed for this deposit [20, 21, 119-121]. Moreover, the oreforming fluids of Liyuan belong to the $\mathrm{H}_{2} \mathrm{O}-\mathrm{CO}_{2}-\mathrm{NaCl} \pm$ $\mathrm{CH}_{4}$ system with the characteristics of medium temperature (mostly $<400^{\circ} \mathrm{C}$ ), enrichment of $\mathrm{CO}_{2}$, and medium-low salinities $(<12.4 \mathrm{wt} \% \mathrm{NaCl}$ equivalent). They are very different from typical magmatic fluids, which are characterized by high temperature and high salinity [122]. Thus, the Liyuan deposit could not be classified as "intrusion-related gold deposit." The eastern China became part of the Pacific margin tectonic during Jurassic to Cretaceous when the major tectonic transformation from N-S compression to NNE-SSW shearing was gradually completed. Maruyama et al. [123] considered this region as a continental margin orogenic belt, and its landward boundary was the NNE-trending N-S Gravity Lineament (NSGL, Figure 1(b)). The Taihang Mountains are part of the typical NSGL in the central NCC [124]; thus, although far from the eastern margin of NCC, the region could be affected by the subduction of the Paleo-Pacific plate, and large scale fluid circulation, granitic magmatism, and metallogenesis took place during the Jurassic to Cretaceous in the TM region.

\section{Conclusions}

(1) The Liyuan deposit is a structurally controlled gold deposit in the Taihang Mountains region of central NCC. The mineralization at Liyuan can be subdivided into three stages: an early quartz stage, a middle quartz-polymetallic stage, and a late quartz-carbonate stage.

(2) Three types of primary fluid inclusions are identified: the aqueous-carbonic (C-type), pure carbonic (PC-type), and aqueous fluid inclusions (W-type). The early and middle stage quartz crystals contain all three types of primary fluid inclusions, and the late stage quartz and calcite contain only $\mathrm{W}$-type inclusions.

(3) The initial ore-forming fluids were either magmatic water, possibly derived from a concealed granite body, or metamorphic water, directly transported via deep faults from deep crust, and meteoric water played an increasing important role during the fluid evolution and in particular in the late stage.

(4) Pressure drop, temperature decrease, and the additional $\mathrm{CH}_{4}$ derived from water-rock interaction caused large scale fluid immiscibility in the middle stage at pressures of 131-224 MPa. Fluid-rock interaction between ore-bearing fluids and iron-bearing wall rock is interpreted to be the main mechanisms of gold deposition at Liyuan.

(5) The Liyuan gold deposit shares many similar features with those of orogenic gold deposits worldwide, and therefore we suggest that this deposit belongs to orogenic type gold deposit.

\section{Conflicts of Interest}

The authors declare that they have no conflicts of interest.

\section{Acknowledgments}

The authors are grateful to Mr. Pu W, Lei HL, Dr. Zhao KD, He MC, Chen W, and Dai X for their help with the lab work. This work was financially supported by China Geological Survey Project (no. 12120115036801) and the MOST Special Fund from the State Key Laboratory of Geological Processes and Mineral Resources, China University of Geosciences (no. MSFGPMR03-2). The authors thank the staffs from the Lingqiu Liyuan Mining Co. Ltd. for their help during the field work and sampling.

\section{References}

[1] D. I. Groves, R. J. Goldfarb, M. Gebre-Mariam, S. G. Hagemann, and F. Robert, "Orogenic gold deposits: a proposed classification in the context of their crustal distribution and relationship to other gold deposit types," Ore Geology Reviews, vol. 13, no. 1-5, pp. 7-27, 1998.

[2] R. J. Goldfarb, D. I. Groves, and S. Gardoll, "Orogenic gold and geologic time: a global synthesis," Ore Geology Reviews, vol. 18, no. 1-2, pp. 1-75, 2001.

[3] D. K. Weatherley and R. W. Henley, "Flash vaporization during earthquakes evidenced by gold deposits," Nature Geoscience, vol. 6, no. 4, pp. 294-298, 2013.

[4] D. I. Groves, "The crustal continuum model for late-Archaean lode-gold deposits of the Yilgarn Block, Western Australia," Mineralium Deposita, vol. 28, no. 6, pp. 366-374, 1993.

[5] Y.-J. Chen, "Orogenic-type deposits and their metallogenic model and exploration potential," Geology in China, vol. 33, no. 6, pp. 1181-1196, 2006.

[6] Y. J. Chen, P. Ni, H. R. Fan et al., "Diagnostic fluid inclusions of different types hydrothermal gold deposits," Acta Petrologica Sinica, vol. 23, no. 9, pp. 2085-2108, 2007.

[7] F. Pirajno, Hydrothermal Processes and Mineral Systems, Springer, Perth, Australia, 2009.

[8] T. Zhou, R. J. Goldfarb, and G. N. Phillips, “Tectonics and distribution of gold deposits in China: an overview," Mineralium Deposita, vol. 37, no. 3-4, pp. 249-282, 2002.

[9] R. J. Goldfarb, R. D. Taylor, G. S. Collins, N. A. Goryachev, and O. F. Orlandini, "Phanerozoic continental growth and gold metallogeny of Asia," Gondwana Research, vol. 25, no. 1, pp. 48102, 2014.

[10] Y.-F. Xu, P. Ni, G.-G. Wang et al., "Geology, fluid inclusion and stable isotope study of the Huangshan orogenic gold deposit: implications for future exploration along the Jiangshan-Shaoxing fault zone, South China," Journal of Geochemical Exploration, vol. 171, pp. 37-54, 2016. 
[11] C. J. R. Hart, R. J. Goldfarb, Y. Qiu, L. Snee, L. D. Miller, and M. L. Miller, "Gold deposits of the northern margin of the North China craton: multiple late Paleozoic-Mesozoic mineralizing events," Mineralium Deposita, vol. 37, no. 3-4, pp. 326-351, 2002.

[12] J. Mao, R. J. Goldfarb, Z. Zhang, W. Xu, Y. Qiu, and J. Deng, "Gold deposits in the Xiaoqinling-Xiong'ershan region, Qinling mountains, central China," Mineralium Deposita, vol. 37, no. 34, pp. 306-325, 2002.

[13] Y. Qiu, D. I. Groves, N. J. McNaughton, L. Wang, and T. Zhou, "Nature, age, and tectonic setting of granitoid-hosted, orogenic gold deposits of the Jiaodong Peninsula, Eastern North China craton, China," Mineralium Deposita, vol. 37, no. 3-4, pp. 283$305,2002$.

[14] S. Y. Jiang, B. Dai, Y. Jiang, H. Zhao, and M. Hou, "Jiaodong and Xiaoqinling: two orogenic gold provinces formed in different tectonic settings," Acta Petrologica Sinica, vol. 25, no. 11, pp. 2727-2738, 2009.

[15] H. Fan, M. Zhai, K. Yang, and F. Hu, "Late Mesozoic Gold Mineralization in the North China Craton," in Main Tectonic Events and Metallogeny of the North China Craton, Springer Geology, pp. 511-525, Springer Singapore, Singapore, 2016.

[16] S. Y. Niu, L. J. Guo, and L. S. Wang, "The study of orecontrolling structure of gold deposits in the northern Taihang Mountains," Mineral Resources and Geology, vol. 8, pp. 192-196, 1994 (Chinese).

[17] S. Y. Niu, A. Q. Sun, C. S. Xu, D. W. Luo, Z. G. Shao, and R. Li, "Metallogenesis study on gold deposits related to detached zone in middle-north part of Taihang Mountains," Journal Geology \& Mineral Resources North China, vol. 12, pp. 67-74, 1997.

[18] Y. Chen, G. Guo, and X. Li, "Metallogenic geodynamic background of Mesozoic gold deposits in granite-greenstone terrains of North China Craton," Science in China Series D: Earth Sciences, vol. 41, no. 2, pp. 113-120, 1998 (Chinese).

[19] Y. Q. Tian, A. J. Wang, K. R. Yu, and W. L. Xu, "Metallogenic geodynamic of vein gold deposit in Wutai-Hengshan region, Shanxi province," Journal Geology \& Mineral Resources North China, vol. 13, pp. 1-89, 1998.

[20] S.-R. Li, M. Santosh, H.-F. Zhang et al., "Inhomogeneous lithospheric thinning in the central North China Craton: Zircon U-Pb and S-He-Ar isotopic record from magmatism and metallogeny in the Taihang Mountains," Gondwana Research, vol. 23, no. 1, pp. 141-160, 2013.

[21] S. Wang, J. Hu, Y. Song, X. Cai, and T. Wang, "Stable isotopic geochemical and geochronological constraints on the formation of the Shihu gold deposit: the intracontinental metallogeny of the Taihang tectonic belt, Eastern China," Resource Geology, vol. 65, no. 3, pp. 249-265, 2015.

[22] Y. Cao, S. Li, H. Zhang, C. Ao, Z. Li, and X. Liu, "Laser probe ${ }^{40} \mathrm{Ar} /{ }^{39} \mathrm{Ar}$ dating for quartz from auriferous quartz veins in the Shihu gold deposit, western Hebei Province, North China," Chinese Journal of Geochemistry, vol. 29, no. 4, pp. 438-445, 2010.

[23] Y. Cao, S. R. Li, M. J. Yao, H. F. Zhang, S. Q. Jiang, and H. P. Niu, "Isotope geochemistry of the Shihu gold deposit, Hebei Province, North China: implication for the source of ore fluid and materials," Carpatbian Journal of Earth and Environment Sciences, vol. 6, pp. 235-249, 2011.

[24] Y. Cao, E. J. M. Carranza, S. Li, M. Yao, and H. Zhang, "Source and evolution of fluids in the Shihu gold deposit, Taihang Mountains, China: evidence from microthermometry, chemical composition and noble gas isotope of fluid inclusions,"
Geochemistry: Exploration, Environment, Analysis, vol. 12, no. 2, pp. 177-191, 2012.

[25] X. P. Xu, "Characteristics and genesis of Liyuan gold deposit in Lingqiu County, Shanxi province," North China Land and Resources, vol. 3, pp. 3-5, 2009 (Chinese).

[26] P. J. Ju, J. Q. Lai, H. J. Yang et al., "Characteristics of fluid inclusions and mineralization of Liyuan Gold Deposit in Lingqiu County," The Chinese Journal of Nonferrous Metals, vol. 25, pp. 2537-2549, 2015.

[27] D. I. Groves and M. Santosh, "Province-scale commonalities of some world-class gold deposits: Implications for mineral exploration," Geoscience Frontiers, vol. 6, no. 3, pp. 389-399, 2015.

[28] Z.-J. Zhou, Y.-J. Chen, S.-Y. Jiang, H.-X. Zhao, Y. Qin, and C.$\mathrm{J} . \mathrm{Hu}$, "Geology, geochemistry and ore genesis of the Wenyu gold deposit, Xiaoqinling gold field, Qinling Orogen, southern margin of North China Craton," Ore Geology Reviews, vol. 59, pp. 1-20, 2014.

[29] J.-W. Li, S.-J. Bi, D. Selby et al., "Giant Mesozoic gold provinces related to the destruction of the North China craton," Earth and Planetary Science Letters, vol. 349-350, pp. 26-37, 2012.

[30] H. P. Taylor Jr., "The application of oxygen and hydrogen isotope studies to problems of hydrothermal alteration and ore deposition," Economic Geology, vol. 69, no. 6, pp. 843-883, 1974.

[31] R. J. Goldfarb, R. Ayuso, M. L. Miller et al., "The late cretaceous Donlin Creek gold deposit, Southwestern Alaska: Controls on epizonal ore formation," Economic Geology, vol. 99, no. 4, pp. 643-671, 2004.

[32] P. E. Brown, "Flincor: a microcomputer program for the reduction and investigation of fluid-inclusion data," American Mineralogist, vol. 74, no. 11-12, pp. 1390-1393, 1989.

[33] T. S. Bowers and H. C. Helgeson, "Calculation of the thermodynamic and geochemical consequences of nonideal mixing in the system $\mathrm{H}_{2} \mathrm{O}-\mathrm{CO}_{2}-\mathrm{NaCl}$ on phase relations in geologic systems: Equation of state for $\mathrm{H}_{2} \mathrm{O}-\mathrm{CO}_{2}-\mathrm{NaCl}$ fluids at high pressures and temperatures," Geochimica et Cosmochimica Acta, vol. 47, no. 7, pp. 1247-1275, 1983.

[34] R. N. Clayton, J. R. O’Neil, and T. K. Mayeda, “Oxygen isotope exchange between quartz and water," Journal of Geophysical Research, vol. 77, no. 17, pp. 3057-3067, 1972.

[35] M.-G. Zhai and M. Santosh, "The early Precambrian odyssey of the North China Craton: a synoptic overview," Gondwana Research, vol. 20, no. 1, pp. 6-25, 2011.

[36] G. Zhao and M. Zhai, "Lithotectonic elements of Precambrian basement in the North China Craton: review and tectonic implications," Gondwana Research, vol. 23, no. 4, pp. 1207-1240, 2013.

[37] S. A. Wilde, G. Zhao, and M. Sun, "Development of the north china craton during the late archaean and its final amalgamation at $1.8 \mathrm{Ga}$ : some speculations on its position within a global palaeoproterozoic supercontinent," Gondwana Research, vol. 5, no. 1, pp. 85-94, 2002.

[38] T. Kusky, J. Li, and M. Santosh, “The Paleoproterozoic North Hebei Orogen: North China craton's collisional suture with the Columbia supercontinent," Gondwana Research, vol. 12, no. 1-2, pp. 4-28, 2007.

[39] Q.-Y. Yang and M. Santosh, "Paleoproterozoic arc magmatism in the North China Craton: no siderian global plate tectonic shutdown," Gondwana Research, vol. 28, pp. 82-105, 2014.

[40] D. Y. Liu, R. W. Page, W. Compston, and J. Wu, "U-Pb zircon geochronology of Precambrian meta-morphic rocks in the 
Taihangshan-Wutaishan area, North China," Bulletin of the Chinese Academy of Geological Sciences, vol. 3, pp. 57-79, 1984.

[41] H. Guan, M. Sun, S. A. Wilde, X. Zhou, and M. Zhai, "SHRIMP $\mathrm{U}-\mathrm{Pb}$ zircon geochronology of the Fuping Complex: Implications for formation and assembly of the North China Craton," Precambrian Research, vol. 113, no. 1-2, pp. 1-18, 2002.

[42] S. Liu, Y. Pan, J. Li, Q. Li, and J. Zhang, "Geological and isotopic geochemical constraints on the evolution of the Fuping Complex, North China Craton," Precambrian Research, vol. 117, no. 1-2, pp. 41-56, 2002.

[43] G. Zhao, S. A. Wilde, P. A. Cawood, and M. Sun, "SHRIMP U$\mathrm{Pb}$ zircon ages of the Fuping Complex: implications for Late Archean to Paleoproterozoic accretion and assembly of the North China Craton," American Journal of Science, vol. 302, no. 3, pp. 191-226, 2002.

[44] Z. L. Shi and F. S. Liu, "Metallogenic systems about Mesozoic metalliferous deposits in north Taihang-Yanshan area," Earth Science Frontiers, vol. 6, pp. 297-304, 1999 (Chinese).

[45] J. H. Cai, G. H. Yan, Z. S. Chang, X. F. Wang, H. X. Shao, and Z. Y. Chu, "Petrological and geochemical characteristics of Wanganzhen complex and discussion on its genesis," Acta Petrologica Sinica, vol. 19, pp. 81-92, 2003.

[46] K. Qu, G. C. Dong, S. R. Li, J. F. Shen, and X. Wang, “The Cu-Mo mineralized diorite porphyry at Mujicun, northern Taihang Mt. and its tectonic significance," Earth Science Frontiers, vol. 28, pp. 449-460, 2012.

[47] G. Dong, M. Santosh, S. Li et al., "Mesozoic magmatism and metallogenesis associated with the destruction of the North China Craton: evidence from $\mathrm{U}-\mathrm{Pb}$ geochronology and stable isotope geochemistry of the Mujicun porphyry Cu-Mo deposit," Ore Geology Reviews, vol. 53, pp. 434-445, 2013.

[48] J. A. Shao, M. G. Zhai, and D. M. Li, "Identification of five stages old dike swarms in the Shanxi-Hebei Inner-Mongalia border area and its implication," Acta Geologica Sinica, vol. 78, no. 1, pp. 320-330, 2004.

[49] Z. H. Luo, Y. Wei, H. T. Xin et al., "The Mesozoic intraplate orogeny of the Taihang Mountains and the thinning of the continental lithosphere in North China," Earth Science Frontiers, vol. 13, pp. 52-63, 2006.

[50] W.-Y. Sun, S.-R. Li, M. Santosh, X. Wang, and L.-J. Zhang, "Isotope geochemistry and geochronology of the qiubudong silver deposit, central north china craton: Implications for ore genesis and lithospheric dynamics," Ore Geology Reviews, vol. 57, pp. 229-242, 2014.

[51] W. Y. Sun, S. R. Li, M. Santosh, and X. Y. Zhang, "Isotope geochemistry and Re-Os geochronology of the Yanjiagou Mo deposit in the central North China Craton," Geological Journal, vol. 50, no. 4, pp. 509-529, 2015.

[52] S. Y. Niu, L. Chen, and C. S. Xu, The crustal evolutioon and metallogenic regularity of the Taihangshan Area, Seismic Publishing House, Beijing, China, 1994.

[53] S. Y. Niu, C. Chen, and A. Q. Sun, "Metallogenic geological characteristics of Shihu gold deposit in the western Hebei Province," Gold Science \& Technology, vol. 16, pp. 1056-1066, 2008.

[54] Y. Q. Cheng, Introduction to the Regional Geology of China, Geological Publishing House, Beijing, China, 1994.

[55] Y. F. Gao, R. H. Wei, Z. Q. Hou et al., "Mujicun porphyry copper mineralization: response to Mesozoic thinning of lithosphere in North China Craton," Mineral Deposits, vol. 30, pp. 890-902, 2012.
[56] Z. C. Shen, Z. Q. Hou, F. Yu et al., "SHRIMP zircon U-Pb ages and Hf isotopes of the intermediate-acidic rocks of Wanganzhan complex in northern part of Taihang Mountains and their geological impliacations," Acta Petrologica Sinica, vol. 31, pp. 1409-1420, 2015.

[57] Y. Liu, C. M. Li, Y. Q. Mu, H. Sun, F. X. Huang, and J. Zheng, "Zircon SHRIMP U-Pb age of Chiwawu granite complex and its implications in the northern Taihang Mountain," Geology and Exploration, vol. 46, pp. 442-447, 2010.

[58] Y. Liu, C. M. Li, J. Zheng et al., "Zircon SHRIMP U-Pb age of Mapeng granite complex and its implications in the northern Taihang Mountain," Geology and Exploration, vol. 46, pp. 622627,2010

[59] X.-F. He and M. Santosh, "Crustal recycling through intraplate magmatism: evidence from the Trans-North China Orogen," Journal of Asian Earth Sciences, vol. 95, pp. 147-163, 2014.

[60] X. Cao, S. Li, L. Xu et al., "Mesozoic-Cenozoic evolution and mechanism of tectonic geomorphology in the central North China Block: constraint from apatite fission track thermochronology," Journal of Asian Earth Sciences, vol. 114, pp. 41-53, 2015.

[61] R. J. Bodnar, "Revised equation and table for determining the freezing point depression of $\mathrm{H} 2 \mathrm{O}-\mathrm{Nacl}$ solutions," Geochimica et Cosmochimica Acta, vol. 57, no. 3, pp. 683-684, 1993.

[62] P. L. F. Collins, "Gas hydrates in $\mathrm{CO}_{2}$-bearing fluid inclusions and the use of freezing data for estimation of salinity," Economic Geology, vol. 74, no. 6, pp. 1435-1444, 1979.

[63] E. Roedder, "Fluid inclusions," Reviews in Mineralogy, vol. 12, pp. 1-644, 1984.

[64] H. Z. Lu, H. R. Fan, P. Ni, G. X. Ou, K. Shen, and W. H. Zhang, Fluid Inclusion, Science Press, Beijing, China, 2004.

[65] L. S. Hollister, "Enrichment of $\mathrm{CO}_{2}$ in fluid inclusions in quartz by removal of $\mathrm{H}_{2} \mathrm{O}$ during crystal-plastic deformation," Journal of Structural Geology, vol. 12, no. 7, pp. 895-901, 1990.

[66] M. Cathelineau, M. C. Boiron, S. Essarraj, M. Lespinasse, and E. Sellie, "Fluid density changes in Au quartz veins: the role of pressure fluctuations and post-trapping changes," Eleventh Biennial Symposium, European Current Research on Fluid Inclusions, Firenze, Pliniu, vol. 5, no. 1, pp. 38-39, 1991.

[67] R. J. Bodnar, "Reequilibration of fluid inclusions," in Fluid inclusions: Analysis and Interpretation, I. Samson, A. Anderson, and D. Marshall, Eds., vol. 32 of Mineralogical Association of Canada Short Course Series, pp. 213-230, 2003.

[68] S. F. Xiong, Z. J. Ding, S. Z. Yao et al., "Characteristics of ore-forming fluid of Yangzhaiyu gold deposit in Xiaoqinling district, Henan Province," Mineral Deposits, vol. 32, pp. 12491261, 2013.

[69] Z.-L. Wang, L.-Q. Yang, L.-N. Guo et al., "Fluid immiscibility and gold deposition in the Xincheng deposit, Jiaodong Peninsula, China: a fluid inclusion study," Ore Geology Reviews, vol. 65, no. 3, pp. 701-717, 2015.

[70] L.-Q. Yang, J. Deng, L.-N. Guo, Z.-L. Wang, X.-Z. Li, and J.-L. $\mathrm{Li}$, "Origin and evolution of ore fluid, and gold-deposition processes at the giant Taishang gold deposit, Jiaodong Peninsula, eastern China," Ore Geology Reviews, vol. 72, no. 1, pp. 585-602, 2016.

[71] G. Chi and C. Xue, "Abundance of $\mathrm{CO}_{2}$-rich fluid inclusions in a sedimentary basin-hosted $\mathrm{Cu}$ deposit at Jinman, Yunnan, China: implications for mineralization environment and classification of the deposit," Mineralium Deposita, vol. 46, no. 4, pp. 365-380, 2011. 
[72] C. Ramboz, M. Pichavant, and A. Weisbrod, "Fluid immiscibility in natural processes: use and misuse of fluid inclusion data. II. Interpretation of fluid inclusion data in terms of immiscibility," Chemical Geology, vol. 37, no. 1-2, pp. 29-48, 1982.

[73] L. S. Hollister, "On the origin of $\mathrm{CO}_{2}$-rich fluid inclusions in migmatites," Journal of Metamorphic Geology, vol. 6, no. 4, pp. 467-474, 1988.

[74] J. Neng, X. Jiuhua, and S. Mianxin, "Fluid inclusion characteristics of mesothermal gold deposits in the Xiaoqinling district, Shaanxi and Henan provinces, People's Republic of China," Mineralium Deposita, vol. 34, no. 2, pp. 150-162, 1999.

[75] D. M. Lawrence, P. J. Treloar, A. H. Rankin, A. Boyce, and P. Harbidge, "A fluid inclusion and stable isotope study at the loulo mining district, Mali, West Africa: implications for multifluid sources in the generation of orogenic gold deposits," Economic Geology, vol. 108, no. 2, pp. 229-257, 2013.

[76] T. J. Shepherd, A. H. Rankin, and D. H. M. Alderton, A Practical Guide to Fluid Inclusion Studies, vol. 18, Blackie, London, UK, 1985.

[77] B. W. D. Yardley and R. J. Bodnar, "Fluids in the Continental Crust," Geochemical Perspectives, vol. 3, no. 1, pp. 20-38, 2014.

[78] Z. Qiu, H. Fan, X. Liu et al., "Fluid inclusion and carbonoxygen isotope studies of the hujiayu cu deposit, Zhongtiao Mountains, China: implications for syn-metamorphic copper remobilization," Acta Geologica Sinica, vol. 89, no. 3, pp. 726745, 2015.

[79] R. H. Goldstein and T. J. Reynolds, "Systematics of fluid inclusions in diagenitic minerals," Society for Sedimentary Geology SEMP Short Course, vol. 31, pp. 87-121, 1994.

[80] S. Xiong, M. He, S. Yao et al., "Fluid evolution of the Chalukou giant Mo deposit in the northern Great Xing'an Range, NE China," Geological Journal, vol. 50, no. 6, pp. 720-738, 2015.

[81] E. Roedder and R. J. Bodnar, "Geologic pressure determinations from fluid inclusion studies," Annual Review of Earth And Planetary Sciences, vol. 8, pp. 263-301, 1980.

[82] H. R. Fan, M. G. Zhai, Y. H. Xie, and J. H. Yang, "Ore-forming fluids associated with granite-hosted gold mineralization at the Sanshandao deposit, Jiaodong gold province, China," Mineralium Deposita, vol. 38, no. 6, pp. 739-750, 2003.

[83] L. N. Guo, R. J. Goldfarb, Z. L. Wang, R. H. Li, B. H. Chen, and J. L. Li, "A comparison of Jiaojia- and Linglong-type gold deposit ore-forming fluids: do they differ?” Ore Geology Reviews, 2016.

[84] R. J. Bodnar, P. Lecumberri-Sanchez, D. Moncada, and M. Steele-MacInnis, "Fluid inclusions in hydrothermal ore deposits," Treatise on Geochemistry: Second Edition, vol. 13, pp. 119-142, 2013.

[85] R. H. Sibson, F. Robert, and K. H. Poulsen, "High-angle reverse faults, fluid-pressure cycling, and mesothermal gold-quartz deposits," Geology, vol. 16, no. 6, pp. 551-555, 1988.

[86] R. Kerrich, R. J. Goldfarb, D. I. Groves, S. Garwin, and Y. Jia, "The characteristics, origins, and geodynamic settings of supergiant gold metallogenic provinces," Science in China, Series D: Earth Sciences, vol. 43, pp. 1-68, 2000.

[87] S. W. Yue, X. H. Deng, L. Bagas et al., "Fluid inclusion geochemistry and $40 \mathrm{Ar} / 39 \mathrm{Ar}$ geochronology constraints on the genesis of the Jianchaling Au deposit, China," Ore Geology Reviews, vol. 80, pp. 676-690, 2017.

[88] J. Naden and T. J. Shepherd, "Role of methane and carbon dioxide in gold deposition," Nature, vol. 342, no. 6251, pp. 793$795,1989$.
[89] B.-J. Wen, H.-R. Fan, F.-F. Hu et al., "Fluid evolution and ore genesis of the giant Sanshandao gold deposit, Jiaodong gold province, China: constrains from geology, fluid inclusions and $\mathrm{H}-\mathrm{O}-\mathrm{S}-\mathrm{He}-\mathrm{Ar}$ isotopic compositions," Journal of Geochemical Exploration, vol. 171, pp. 96-112, 2016.

[90] E. M. Hendel and L. S. Hollister, "An empirical solvus for $\mathrm{CO}_{2}$ $\mathrm{H}_{2} \mathrm{O}-2.6$ wt\% salt," Geochimica et Cosmochimica Acta, vol. 45, no. 2, pp. 225-228, 1981.

[91] P. Hugh and J. R. Taylor, "The application of oxygen and hydrogen isotope studies to problems of hydrothermal alteration and ore deposition," Economic Geology, vol. 69, no. 6, pp. 843-883, 1974.

[92] G. Faure, Principles of Isotope Geology, John Wiley and Sons, Inc., New York, NY, USA, 2nd edition, 1986.

[93] J. Hoefs, Stable Isotope Geochemistry, Springer, Berlin, Heidelberg, 1997.

[94] R. J. Goldfarb and D. I. Groves, "Orogenic gold: common or evolving fluid and metal sources through time," Lithos, vol. 233, pp. 2-26, 2015.

[95] M. Gebre-Mariam, S. G. Hagemann, and D. I. Groves, "A classification scheme for epigenetic Archaean lode-gold deposits," Mineralium Deposita, vol. 30, no. 5, pp. 408-410, 1995.

[96] J. Kolb and M. F. Meyer, "Fluid inclusion record of the hypozonal orogenic Renco gold deposit (Zimbabwe) during the retrograde P-T evolution," Contributions to Mineralogy and Petrology, vol. 143, no. 4, pp. 495-509, 2002.

[97] R. J. Goldfarb, D. L. Leach, W. J. Pickthorn, and C. J. Paterson, "Origin of lode-gold deposits of the Juneau gold belt, southeastern Alaska," Geology, vol. 16, no. 5, pp. 440-443, 1988.

[98] W. K. Witt, J. T. Knight, and E. J. Mikucki, "A synmetamorphic lateral fluid flow model for gold mineralization in the Archean southern Kalgoorlie and Norseman terranes, Western Australia," Economic Geology, vol. 92, no. 4, pp. 407-437, 1997.

[99] S.-G. Choi, S.-T. Kwon, J.-H. Ree, C.-S. So, and S. J. Pak, "Origin of Mesozoic gold mineralization in South Korea," Island Arc, vol. 14, no. 2, pp. 102-114, 2005.

[100] X.-H. Zhang, Q. Liu, Y.-J. Ma, and H. Wang, “Geology, fluid inclusions, isotope geochemistry, and geochronology of the Paishanlou shear zone-hosted Gold Deposit, North China Craton," Ore Geology Reviews, vol. 26, no. 3-4, pp. 325-348, 2005.

[101] F. Pirajno and L. Bagas, "A review of Australia's Proterozoic mineral systems and genetic models," Precambrian Research, vol. 166, no. 1-4, pp. 54-80, 2008.

[102] B. C. Yoo, H. K. Lee, and N. C. White, "Mineralogical, fluid inclusion, and stable isotope constraints on mechanisms of ore deposition at the Samgwang mine (Republic of Korea)a mesothermal, vein-hosted gold-silver deposit," Mineralium Deposita, vol. 45, no. 2, pp. 161-187, 2010.

[103] M. Cao, K. Qin, G. Li, N. J. Evans, and L. Jin, "Abiogenic FischerTropsch synthesis of methane at the Baogutu reduced porphyry copper deposit, western Junggar, NW-China," Geochimica et Cosmochimica Acta, vol. 141, pp. 179-198, 2014.

[104] T. M. Seward, "Thio complexes of gold and the transport of gold in hydrothermal ore solutions," Geochimica et Cosmochimica Acta, vol. 37, no. 3, pp. 379-399, 1973.

[105] K.-I. Hayashi and H. Ohmoto, "Solubility of gold in NaCl-and $\mathrm{H}_{2} \mathrm{~S}$-bearing aqueous solutions at $250-350^{\circ} \mathrm{C}$," Geochimica et Cosmochimica Acta, vol. 55, no. 8, pp. 2111-2126, 1991.

[106] A. Stefánsson and T. M. Seward, "Stability of chloridogold(I) complexes in aqueous solutions from 300 to $600 \circ \mathrm{C}$ and from 
500 to 1800 bar," Geochimica et Cosmochimica Acta, vol. 67, no. 23, pp. 4559-4576, 2003.

[107] A. Stefánsson and T. M. Seward, "Gold(I) complexing in aqueous sulphide solutions to $500 \circ \mathrm{C}$ at 500 bar," Geochimica et Cosmochimica Acta, vol. 68, no. 20, pp. 4121-4143, 2004.

[108] C. H. Gammons, A. E. Williams-Jones, and Y. Yu, "New data on the stability of gold(I) chloride complexes at $300^{\circ} \mathrm{C}$," Mineralogical Magazine, vol. 58A, no. 1, pp. 309-310, 1994.

[109] D. M. Shenberger and H. L. Barnes, "Solubility of gold in aqueous sulfide solutions from 150 to 350॰C," Geochimica et Cosmochimica Acta, vol. 53, no. 2, pp. 269-278, 1989.

[110] L. G. Benning and T. M. Seward, "Hydrosulphide complexing of $\mathrm{Au}(\mathrm{I})$ in hydrothermal solutions from $150-400 \circ \mathrm{C}$ and $500-1500$ bar," Geochimica et Cosmochimica Acta, vol. 60, no. 11, pp. 18491871, 1996.

[111] K. Shen, S. X. Hu, J. G. Sun, H. F. Ling, Y. Y. Zhao, and Z. Sun, "Characteristics of ore-forming fluids of the Dayinggezhuang gold deposit in Jiaodong, China," Acta Petrologica Sinica, vol. 16, pp. 542-550, 2000.

[112] E. J. Mikucki, "Hydrothermal transport and depositional processes in Archean lode-gold systems: a review," Ore Geology Reviews, vol. 13, no. 1-5, pp. 307-321, 1998.

[113] D. I. Groves, G. Phillips, S. E. Ho, and S. M. Houstoun, “The nature, genesis and regional controls of gold mineralization in Archaean greenstone belts of the Western Australian Shield; a brief review," South African Journal of Geology, vol. 88, pp. 135$148,1985$.

[114] G. N. Phillips and K. A. Evans, "Role of $\mathrm{CO}_{2}$ in the formation of gold deposits,” Nature, vol. 429, no. 6994, pp. 860-863, 2004.

[115] T. P. Mernagh and A. S. Wygralak, "Gold ore-forming fluids of the Tanami region, Northern Australia," Mineralium Deposita, vol. 42, no. 1-2, pp. 145-173, 2007.

[116] H. Z. Lu, "Role of $\mathrm{CO}_{2}$ fluid in the formation of gold deposits: Fluid inclusion evidences," Geochimica, vol. 37, pp. 321-328, 2008.

[117] D. I. Groves, R. J. Goldfarb, F. Robert, and C. J. R. Hart, "Gold deposits in metamorphic belts: Overview of current understanding, outstanding problems, future research, and exploration significance," Economic Geology, vol. 98, no. 1, pp. 1-29, 2003.

[118] R. Ye, L. S. Zhao, and R. L. Shen, "Geochemistry features of Yixingzhai gold deposit in Shanxi Province," Geoscience, vol. 13, pp. 415-418, 1999.

[119] Q. Li, M. Santosh, and S.-R. Li, "Stable isotopes and noble gases in the Xishimen gold deposit, central North China Craton: metallogeny associated with lithospheric thinning and crustmantle interaction," International Geology Review, vol. 55, no. 14, pp. 1728-1743, 2013.

[120] Q. Li, M. Santosh, S.-R. Li, and J.-Q. Zhang, "Petrology, geochemistry and zircon $\mathrm{U}-\mathrm{Pb}$ and Lu-Hf isotopes of the Cretaceous dykes in the central North China Craton: implications for magma genesis and gold metallogeny," Ore Geology Reviews, vol. 67, pp. 57-77, 2015.

[121] S.-R. Li, M. Santosh, H.-F. Zhang et al., "Metallogeny in response to lithospheric thinning and craton destruction: geochemistry and $\mathrm{U}-\mathrm{Pb}$ zircon chronology of the Yixingzhai gold deposit, central North China Craton," Ore Geology Reviews, vol. 56, pp. 457-471, 2014.

[122] A. Audétat, T. Pettke, C. A. Heinrich, and R. J. Bodnar, "Special paper: the composition of magmatic-hydrothermal fluids in barren and mineralized intrusions," Economic Geology, vol. 103, no. 5, pp. 877-908, 2008.
[123] S. Maruyama, Y. Isozaki, G. Kimura, and M. Terabayashi, "Paleogeographic maps of the Japanese Islands: plate tectonic synthesis from $750 \mathrm{Ma}$ to the present," Island Arc, vol. 6, no. 1, pp. 121-142, 1997.

[124] S.-R. Li and M. Santosh, "Metallogeny and craton destruction: records from the North China Craton," Ore Geology Reviews, vol. 56, pp. 376-414, 2014. 

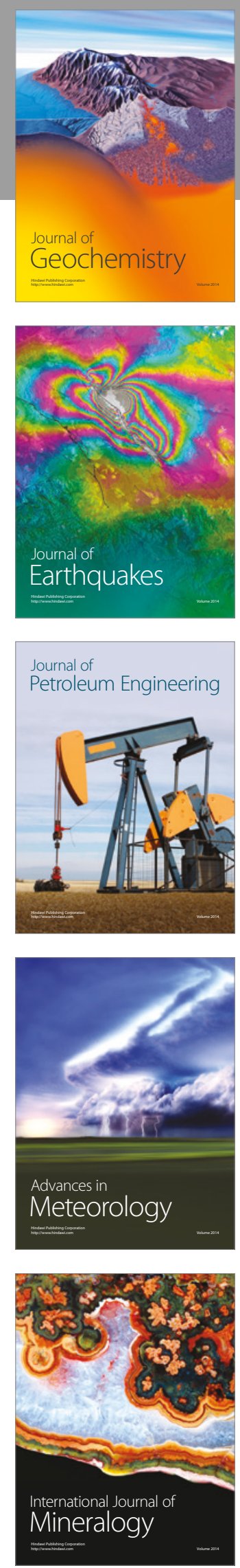
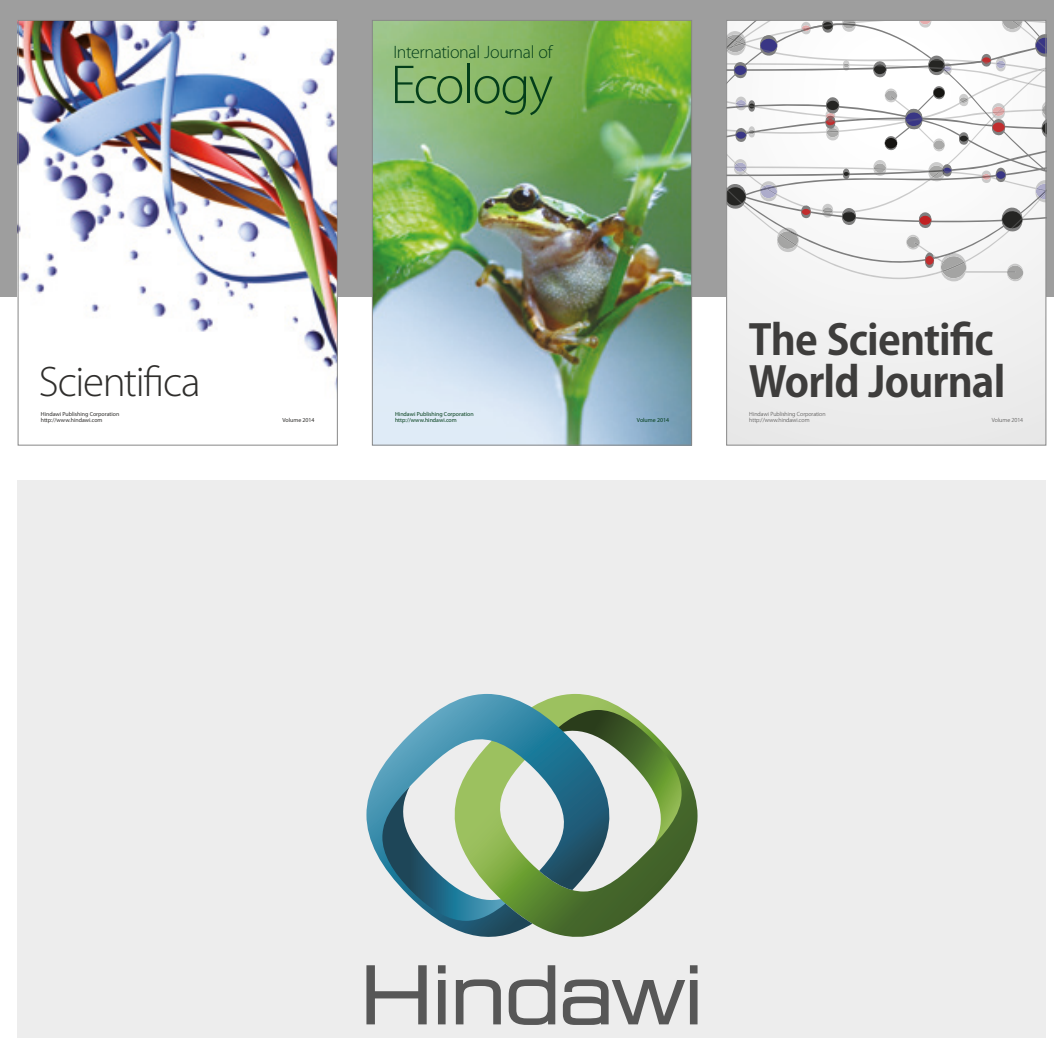

Submit your manuscripts at

https://www.hindawi.com
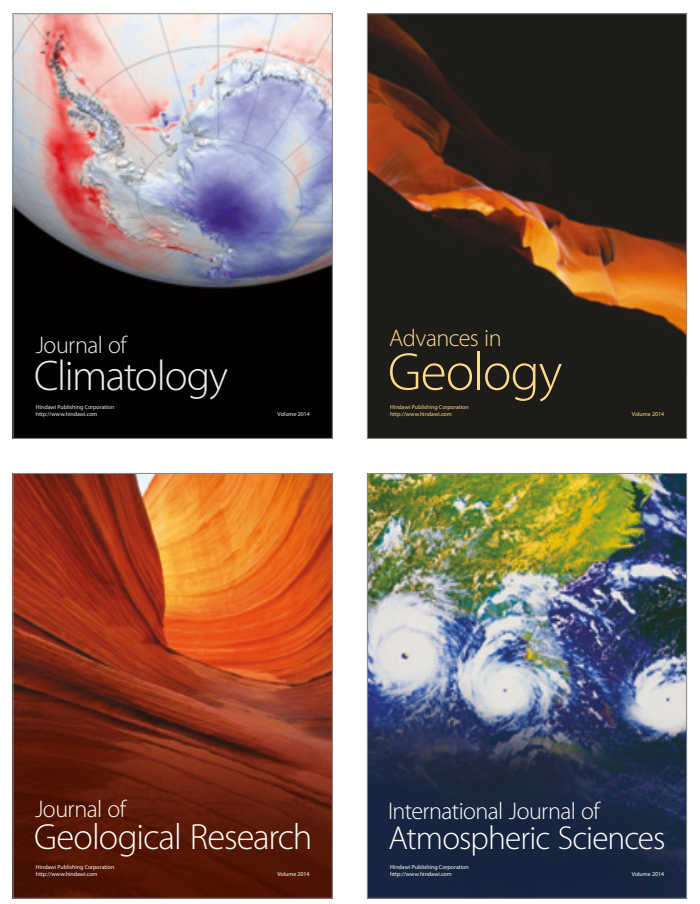

The Scientific

World Journal
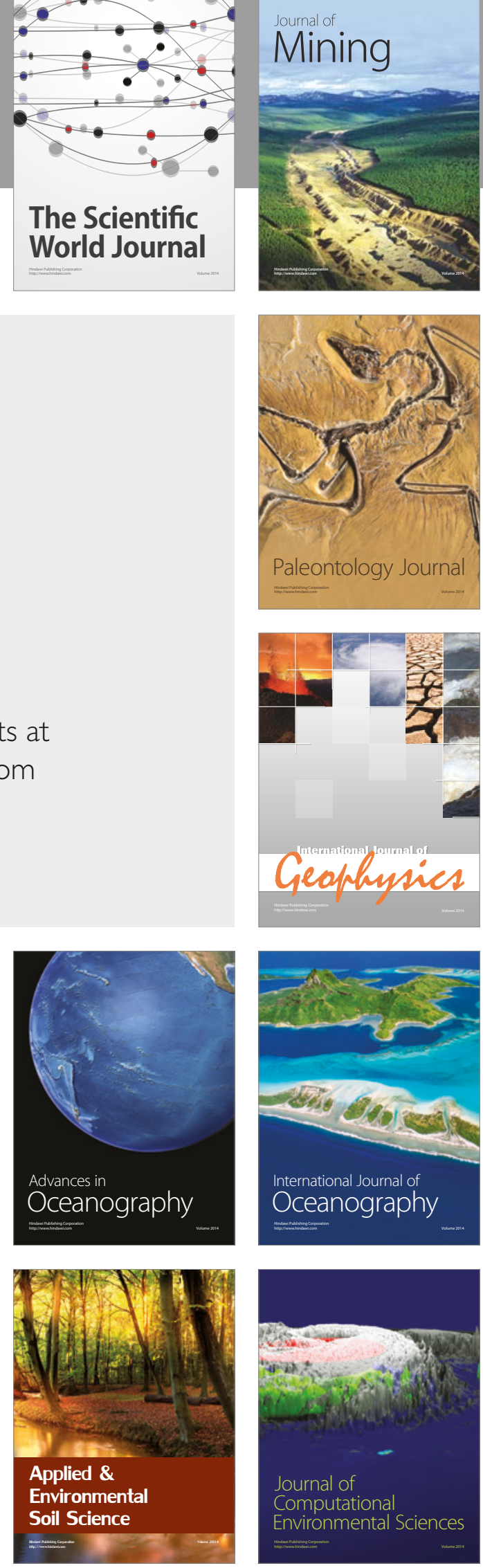